\title{
Class II phosphatidylinositol 3-kinase a and $\beta$ isoforms are required for vascular smooth muscle Rho activation, contraction and blood pressure regulation in mice
}

\author{
Shahidul Islam', Kazuaki Yoshioka', Sho Aki ${ }^{1}$, Kazuhiro Ishimaru' ${ }^{1}$, Hiroki Yamada', Noriko Takuwa ${ }^{1,2}$ \\ and Yoh Takuwa ${ }^{* *}$
}

\begin{abstract}
Class II phosphatidylinositol 3-kinases (PI3K), PI3K-C2 $\alpha$ and PI3K-C2 $\beta$, are involved in cellular processes including endocytosis, cilia formation and autophagy. However, the role of PI3K-C2a and PI3K-C2 $\beta$ at the organismal level is not well understood. We found that double knockout $(\mathrm{KO})$ mice with both smooth muscle-specific KO of PI3K-C2a and global PI3K-C2 $\beta$ KO, but not single KO mice of either PI3K-C2a or PI3K-C2 $\beta$, exhibited reductions in arterial blood pressure and substantial attenuation of contractile responses of isolated aortic rings. In wild-type vascular smooth muscle cells, double knockdown of PI3K-C2 $\alpha$ and PI3K-C2 $\beta$ but not single knockdown of either PI3K markedly inhibited contraction with reduced phosphorylation of 20-kDa myosin light chain and MYPT1 and Rho activation, but without inhibition of the intracellular $\mathrm{Ca}^{2+}$ mobilization. These data indicate that PI3K-C2 $a$ and PI3K-C2 $\beta$ play the redundant but essential role for vascular smooth muscle contraction and blood pressure regulation mainly through their involvement in Rho activation.
\end{abstract}

Keywords: Class II phosphatidylinositol 3-kinase, Vascular smooth muscle, Contraction, Rho, Blood pressure

\section{Introduction}

Phosphatidylinositol 3-kinases (PI3K) are lipid kinases that catalyze the phosphorylation of phosphoinositides at the D3 position of their inositol ring and, thereby, control a diverse array of cellular processes including vesicular trafficking, cell migration, cell proliferation and cell metabolism [1]. Mammals possess eight PI3K isoforms, which are divided into three classes (class I, II and III), based on their structural homology, substrate specificity and mode of regulation [2]. Class I PI3K are activated

\footnotetext{
*Correspondence: ytakuwa@med.kanazawa-u.ac.jp

1 Department of Physiology, Kanazawa University Graduate School

of Medical Sciences, 13-1 Takara-machi, Kanazawa, Ishikawa 920-8640, Japan

Full list of author information is available at the end of the article
}

downstream of various receptor tyrosine kinases and G protein-coupled receptors to mainly generate phosphatidylinositol-3,4,5-trisphosphates and to mediate cell proliferation, survival, and migration. Through these effects, class I PI3K are involved in cancer and allergic diseases. The unique member of class III, Vps34, is responsible for a significant fraction of phosphatidylinositol3-monophosphate in autophagosomes and endosomes, in which it controls the formation of phagophores as well as docking and fusion of endosomes. Class II PI3K, which comprises three isoforms PI3K-C2 $\alpha(\mathrm{C} 2 \alpha)$, PI3K-C2 $\beta$ $(\mathrm{C} 2 \beta)$ and PI3K-C2 $\gamma$, mainly produce phosphatidylinositol-3,4-bisphosphate $\left(\mathrm{PI}(3,4) \mathrm{P}_{2}\right)$ and are involved in endocytosis, autophagy and cilia formation at the cellular level [3-8]. C2 $\alpha$ and $C 2 \beta$ are ubiquitously expressed widely in various organs and tissues whereas PI3K-C2 $\gamma$

(c) The Author(s) 2020. This article is licensed under a Creative Commons Attribution 4.0 International License, which permits use, sharing, adaptation, distribution and reproduction in any medium or format, as long as you give appropriate credit to the original author(s) and the source, provide a link to the Creative Commons licence, and indicate if changes were made. The images or other third party material in this article are included in the article's Creative Commons licence, unless indicated otherwise in a credit line to the material. If material is not included in the article's Creative Commons licence and your intended use is not permitted by statutory regulation or exceeds the permitted use, you will need to obtain permission directly from the copyright holder. To view a copy of this licence, visit http://creativeco mmons.org/licenses/by/4.0/. 
expression is restricted mainly in liver, breast, testis and prostate [9]. C2 $\beta$ is highly homologous in its amino acid sequence to $C 2 \alpha$ and exhibits similar activities including cell migration and growth to those of $\mathrm{C} 2 \alpha$. However, the physiological function of class II PI3K is still poorly understood compared with class I and class III PI3K.

We previously showed that $\mathrm{C} 2 \alpha$, which is clearly less sensitive to the PI3K inhibitors wortmannin and LY294002 [10, 11], was required for membrane depolarization- and receptor agonist-induced contraction of isolated blood vessel strips and vascular smooth muscle cells [12-14]. Moreover, our study suggested that C2 $\alpha$ was involved in Rho activation and Rho kinase-dependent phosphorylation of the myosin-targeting subunit MYPT1 of myosin light chain phosphatase (MLCP) and, thereby, an increase in phosphorylation of $20 \mathrm{kDa}$ regulatory myosin light chain $\left(\mathrm{MLC}_{20}\right)$. We further demonstrated that in vascular smooth muscle of spontaneously hypertensive rats, enhanced activation of $\mathrm{C} 2 \alpha$ contributed to increased Rho activity, elevated vascular tone and hypertension [15]. These observations suggested that $\mathrm{C} 2 \alpha$ is an important regulatory molecule for Rho activation and contraction in vascular smooth muscle.

In order to better understand the role of $\mathrm{C} 2 \alpha$ at the organismal level, we generated $\mathrm{C} 2 \alpha-$ knockout (KO) mice and analyzed their phenotype. Global C2 $\alpha$-homozygous $\mathrm{KO}$ mice were embryonic lethal owing to severe defects of angiogenesis [3]. Endothelial-specific genetic deletion of $\mathrm{C} 2 \alpha$ recapitulated this phenotype. In contrast to $\mathrm{C} 2 \alpha$, global $\mathrm{C} 2 \beta$-homozygous $\mathrm{KO}$ mice were apparently normal [16]. We, therefore, generated smooth muscle-specific $\mathrm{C} 2 \alpha$-deleted mice with or without global $\mathrm{C} 2 \beta \mathrm{KO}$ to study the role of $C 2 \alpha$ and $C 2 \beta$ in vascular smooth muscle contraction. Our data show that single $\mathrm{KO}$ of either $\mathrm{C} 2 \alpha$ or $\mathrm{C} 2 \beta$ did not affect vascular smooth muscle contraction or blood pressure, but that double $\mathrm{KO}$ of $\mathrm{C} 2 \alpha$ and $\mathrm{C} 2 \beta$ resulted in markedly attenuated vascular smooth muscle contraction with impaired Rho activation and decreased blood pressure compared with control mice. These observations indicate that $\mathrm{C} 2 \alpha$ and $\mathrm{C} 2 \beta$ have the essential compensatory role for vascular smooth muscle contraction and blood pressure regulation in mice.

\section{Methods}

\section{Mice}

Mice were housed in a temperature-controlled $\left(24{ }^{\circ} \mathrm{C}\right)$ facility room under a 12-h/12-h light-dark cycle with free access to regular chow and water under specific pathogen-free conditions in the animal facility of the University of Kanazawa. All mouse experiments were performed following the "fundamental guidelines for proper conduct of animal experiment and related activities in academic research institutions" under the jurisdiction of the Ministry of Education, Culture, Sports, Science, and Technology of Japan and were approved by the Committee on Animal Experimentation of Kanazawa University. PI3K-C2 $\alpha$-floxed $\left(\mathrm{C} 2 \alpha^{\text {flox/flox }}\right)$ mice, PI3K-C2 $\beta$-null $\left(\mathrm{C} 2 \beta^{-l-}\right)$ mice, and Rosa26-CAG-loxP-stop-loxP-tdTomato (R26-tdTomato) reporter mice were described previously $[3,17]$. To generate smooth muscle-specific conditional $\mathrm{C} 2 \alpha-\mathrm{KO}$ mice, $\mathrm{C} 2 \alpha^{\text {flox/flox }}$ mice were crossed with SM22 $\alpha$-Cre transgenic mice (\# 004746, Jackson Lab.). To evaluate Cre-mediated recombination efficiency, SM22 $\alpha$-Cre; R26-tdTomato mice were generated. Mice were euthanized using intraperitoneal injections of overdoses of three combined anesthetics, medetomidine (ZENOAQ, Fukushima, Japan), midazolam (Astellas, Tokyo, Japan) and butorphanol (Meiji Seika Pharma, Tokyo, Japan) according to the acceptable euthanasia guidelines. Mice were genotyped by PCR analysis of genomic DNA prepared from tail biopsies.

\section{Immunofluorescent staining of aortic sections}

The perfusion-fixed aortae were embedded in TissueTek OCT compound (Sakura Finetek, Tokyo, Japan), and the prepared sections were blocked with phosphate buffer saline containing $0.1 \%$ Triton X-100, $0.1 \%$ Tween $20,1 \%$ bovine serum albumin, and $5 \%$ non-immune goat serum for $1 \mathrm{~h}$ at room temperature. The cryosections of aorta were subjected to immunofluorescent staining using the following primary antibodies: mouse monoclonal anti- $\alpha$ SMA (\#A5228, Sigma-Aldrich, St. Louis, MO, USA), mouse monoclonal anti-SM22 $\alpha$ (\#ab10135; Abcam, Cambridge, UK), rabbit polyclonal anti-smooth muscle myosin heavy chain 11 (\#ab53219; Abcam), rabbit polyclonal anti-C2 $\alpha$ (\#AP11855B, Abgent, San Diego, CA, USA), rabbit polyclonal anti-C2 $\beta$ (\#sc-134766, Santa Cruz Biotechnology, Dallas, TX, USA). The sections were treated with appropriate Alexa-Fluor conjugated secondary antibodies (Molecular Probes) and, then, mounted with 4',6-diamidino-2-phenylindole (DAPI) for nuclear staining.

\section{Measurement of blood pressure}

Male mice aged 10 to 12 weeks were used. Mice were trained by repeated blood pressure measurements in several trials until the basal condition was stabilized and the consistent and stable reading was monitored. The systolic, diastolic and mean blood pressure with the heart rate of conscious mice was recorded using a tail-cuff system (Softron, Tokyo, Japan) as reported previously [15, $18]$.

\section{Measurements of isometric tension of aortic rings}

The aorta was isolated from control and DKO mice aged 10 to 12 weeks, cleaned free of adhering connective 
tissues and cut into rings of 3-4 mm width in ice-cold modified Krebs-Henseleit buffer as previously described $[12,14]$. Aortic rings were placed in contraction chambers at $37^{\circ} \mathrm{C}$ under the aeration with $95 \% \mathrm{O}_{2}$ and $5 \% \mathrm{CO}_{2}$, and isometric tension was determined with a transducer (\#UFERUM-203, Kishimoto Medical Instruments, Kyoto, Japan) as described previously [12, 14]. Aortic rings were stimulated with various doses of $\mathrm{KCl}$ and noradrenaline (NA) (Cayman Chemical) in cumulative manners. When indicated, aortic rings were pretreated with the Rho kinase inhibitor Y-27632 $(10 \mu \mathrm{M})$ (FUJIFILM Wako Pure Chemical, Osaka, Japan). After tension measurements, aortic rings were fixed in $4 \%$ formalin overnight at $4{ }^{\circ} \mathrm{C}$ and embedded in paraffin, followed by cross-sectioning and Azan staining for the determination of the medial smooth muscle area. Tensions were corrected by a crosssectional medial smooth muscle area in each aortic ring.

\section{Plasmids}

The enhanced green fluorescent protein (GFP)-tagged human PI3K-C2 $\alpha$ (GFP-C2 $\alpha)$ expression vector was previously described [3]. Human PI3K-C2 $\beta$ cDNA was obtained from K. Kitatani (Setsunan University) [19]. To generate mCherry-tagged PI3K-C $2 \alpha$ (mCherry-C2 $\alpha$ ) and GFP- and mCherry-tagged PI3K-C2 $\beta$ (GFP-C2 $\beta$ and mCherry-C2 $\beta$ ), human PI3K-C2 $\alpha$ and PI3K-C2 $\beta$ cDNA fragments were amplified by PCR using Prime STAR HS DNA Polymerase (Takara, Shiga, Japan) and sub-cloned into pmCherry-C1 (Takara) and pAcGFP1$\mathrm{N}$ vectors (Clontech, Mountain View, CA, USA), using the In-Fusion HD Cloning kit (Clontech). The plasmid vectors of RhoA-FRET sensor, pTriEx-RhoA-wt_mScarlet-i_SGFP2 (\#85071, Addgene), and BFP-Rab5 (\#49147; Addgene) were obtained from Dorus Gadella and Gia Voeltz, respectively, through Addgene.

\section{Aortic smooth muscle cells}

Mouse aortic smooth muscle cells (MASM) were isolated from 4-week-old mouse aortae by an enzyme-dispersion method. Briefly, aortae were dissected under sterile conditions and incubated at $37{ }^{\circ} \mathrm{C}$ in $0.1 \%$ collagenase (Type II) (\#LS004202, Worthington Biochemical, Lakewood, NJ, USA), 0.75 unit/mL elastase (Type III) (\#LS002279, Worthington Biochemical) and $0.1 \%$ trypsin inhibitor (\#LS003570, Worthington Biochemical) for $30 \mathrm{~min}$, followed by further incubation of the mixtures for $60 \mathrm{~min}$ after separating the adventitia from aortae. Dispersed single cells were separated from undigested tissues by filtration through Cell Strainers $(100 \mu \mathrm{m})(\# 352360, \mathrm{BD}$ Falcon) and collected by centrifugation at $500 \mathrm{~g}$ for $5 \mathrm{~min}$. Cells thus obtained were plated onto laminin $(20 \mu \mathrm{g} /$ $\mathrm{mL}$ in PBS) (FUJIFILM Wako Pure Chemical Corp. Cat no. 120-05751)-coated glass bottom dishes (MatTek,
Bratislava, Slovakia) with the growth medium SmGM-2, which contains $5 \%$ fetal bovine serum (FBS) and growth factor supplements (\#CC-3182, Lonza, Walkersville MD, USA). Human aortic smooth muscle cells (HASM), which were purchased from Lonza (\#CC-2571, Lonza), were also plated onto laminin-coated dishes and slides with SmGM-2. After cells were cultured for 3 to 4 days, cells were transfected with siRNAs and Lipofectamine RNAiMAX (Invitrogen/Thermo Fisher Scientific) in Opti-MEM (Invitrogen/Thermo Fisher Scientific) by incubating cells with siRNA was 4 to $6 \mathrm{~h}$ and cultured in SmGM2 for $48 \mathrm{~h}$. The concentrations of siRNAs were $50 \mathrm{nM}$ for the transfection of a single siRNA (single transfection) and $25 \mathrm{nM}$ each for the transfection of two siRNAs (double transfection). Our preliminary studies confirmed that 25 and $50 \mathrm{nM}$ of siRNAs in the single transfection and $25 \mathrm{nM}$ of siRNAs in the double transfection gave the similar extents of inhibition of protein expression of our interest. The targeted sequences of siRNA were: 5'-AAG GUU GGC ACU UAC AAG AAU$3^{\prime}$ for human PI3K-C2 $\alpha$ and 5'-AAG CCG GAA GCU UCU GGG UUU-3' for human PI3K-C2 $\beta$ ). The control siRNA sequence was $5^{\prime}$-AAU UCU CCG AACGUG UCA CGU-3'. We transfected cells with GFP- and mCherrytagged PI3K expression vectors using Lipofectamine (Invitrogen/Thermo Fisher Scientific) in Opti-MEM, followed by cultures in the growth medium for 3-4 days. Cells were serum- and growth factor-starved for 1 to $4 \mathrm{~h}$ in DMEM supplemented with $0.1 \%$ fatty acid free BSA (Sigma-Aldrich) for contraction assay, Western blot analyses of phosphorylation of $\mathrm{MLC}_{20}$ and MYPT1, and Rho imaging analyses.

\section{Determinations of contraction and the intracellular free $\mathrm{Ca}^{2+}$ concentration $\left(\left[\mathrm{Ca}^{2+}\right]_{\mathrm{i}}\right)$ of vascular smooth muscle cells}

Cells were loaded with the fluorescent $\mathrm{Ca}^{2+}$ indicator fluo-8 acetoxymethylester (AM) $(2.5 \mu \mathrm{M})$ (Molecular Probes) in Hank's Balanced Salt Solution (HBSS) for $30 \mathrm{~min}$ in the dark at $37^{\circ} \mathrm{C}$, followed by $1 \mathrm{~h}$ starvation with serum-free, phenol red-free FluoroBrite DMEM (Gibco, Thermo Fisher Scientific). After cells were washed with FluoroBrite DMEM two times, cells were imaged in FluoroBrite DMEM at $37{ }^{\circ} \mathrm{C}$ using a confocal microscope (inverted IX70 microscope; Olympus Corp., Tokyo, Japan) equipped with a confocal disk-scanning unit (CSU10, Yokogawa, Tokyo, Japan) as described previously [13]. The acquisition and process were controlled by iQ software (Andor, Belfast, UK). For evaluations of cell contraction, a stimulus-induced reduction in the planar cell surface area, which was sharply visualized by Fluo-8 fluorescence, was determined and expressed as a stimulus-induced change $(\Delta A)$ of the planar cell area over 
the planar cell area before stimulation $\left(A_{0}\right)[12,13]$. A stimulus-induced change in the $\left[\mathrm{Ca}^{2+}\right]_{i}$ was determined using the fluorescent $\mathrm{Ca}^{2+}$ indicator Fluo-8 as described previously [13]. Changes in Fluo-8 fluorescence were monitored every $10 \mathrm{~s}$ with excitation at $488 \mathrm{~nm}$ light and emission fluorescence at $510 \mathrm{~nm}$. The ratio of ionomycinstimulated fluorescence intensity over basal intensity was calculated.

\section{Fluorescence resonance energy transfer (FRET) imaging for Rho activation}

For FRET imaging analysis, HASM were transfected with the RhoA-FRET sensor probe $[3,17]$ using an Amaxa Nucleofector system (Lonza) and plated onto laminin-coated, glass-bottomed culture dishes. For the measurements of RhoA-FRET signals, the ratio imaging was carried out on the Dragonfly confocal system (Andor) equipped with the Andor's spinning-disk unit and EMCCD camera (iXon DU888) based on an inverted Nikon Eclipse Ti2 microscope (Nikon Instrument, Tokyo Japan). Cells were stimulated with either ionomycin (IMC) $(0.3 \mu \mathrm{M})$ or endothelin-1 (ET-1) $(1 \mu \mathrm{M})$, after 2 min observations as baseline signals. Pseudo-color ratio images were generated from images from GFP and FRET channels using Andor iQ software. RhoA-FRET signal intensity within ten subcellular regions per cell at $3 \mathrm{~min}$ after the addition of agonists was quantified. The ratio of ionomycin- and endothelin-stimulated fluorescence intensity/basal intensity was expressed. In some experiments, the co-localization of RhoA-FRET signals and blue fluorescent protein-Rab5 signals was evaluated.

\section{Immunofluorescence staining of cells}

HASM were cultured in SmGM2 at $37{ }^{\circ} \mathrm{C}$ under $5 \%$ $\mathrm{CO}_{2}$. Cells of the passage number between 5 and 6 were used for experiments. Cells were rinsed with Dulbecco's phosphate-buffered saline (PBS) once and fixed with $4 \%$ paraformaldehyde in $0.1 \mathrm{M}$ phosphate buffer ( $\mathrm{pH}$ 7.4) for $10 \mathrm{~min}$ at room temperature, followed by permeabilization with $0.3 \%$ TritonX-100 in PBS for 15 min or with $90 \%$ chilled methanol for $5 \mathrm{~min}$. After blocking in $5 \%$ normal goat serum (FUJIFILM Wako Pure Chemical Corp.) and $0.3 \%$ TritonX-100 in PBS, cells were incubated with rabbit polyclonal anti-clathrin heavy chain (1:400) (\#ab21679, Abcam) overnight at $4{ }^{\circ} \mathrm{C}$. After washing, cells were incubated with an appropriate Alexa-Fluor-conjugated secondary antibody (Molecular Probes) for $1 \mathrm{~h}$ at room temperature.

\section{Immunoblot analyses}

Cells were quickly washed with PBS 48-72 h after siRNA transfection and scraped into either $2 \times$ Laemmli's SDS sample buffer or the RIPA lysis buffer on ice. For determination of $\mathrm{MLC}_{20}$ and MYPT1 phosphorylation, cells were quickly rinsed and quenched by adding an ice-cold stop buffer containing $10 \%$ trichloroacetic acid, $150 \mathrm{mM} \mathrm{NaCl}, 2 \mathrm{mM}$ DTT and $4 \mathrm{mM}$ EGTA, followed by scraping into $2 \times$ Laemmli's SDS sample buffer. The $\mathrm{pH}$ of cell lysates was neutralized by adding a concentrated Tris solution. Cell lysates were then boiled for $5 \mathrm{~min}$ and centrifuged for $5 \mathrm{~min}$ at 15,000 rpm. The resultant supernatants were separated on 8 to $15 \%$ SDS-PAGE, followed by electro-transfer onto polyvinylidene difluoride membranes (Immobilon-P, Millipore-Merck, Nottingham, UK) using the Trans-Blot Turbo blotting system (Bio-Rad, Hercules, CA, USA). After blocking, membranes were incubated with primary antibodies at $4{ }^{\circ} \mathrm{C}$ overnight. The antibodies used were: rabbit monoclonal anti-PI3K-C2 $\alpha$ (1:1000) (\#12402; CST), mouse monoclonal anti-PI3K-C2 $\beta$ (1:500) (\#611342, BD Biosciences, San Diego, CA USA), rabbit polyclonal anti-Mhc11 (1:1000) (\#ab53219; Abcam), monoclonal anti-20 kDa myosin light chain $\left(\mathrm{MLC}_{20}\right)(1: 1000)$ (\#M4401, Sigma-Aldrich), rabbit polyclonal anti-phospho-MLC ${ }_{20}\left(\operatorname{Ser}^{19}\right)(1: 500)(\# 3671$, CST), rabbit polyclonal anti-phospho- $\mathrm{MLC}_{20}\left(\mathrm{Thr}^{18} /\right.$ $\operatorname{Ser}^{19}$ ) (1:500) (\#3674, CST), mouse monoclonal antimyosin light chain kinase (MLCK) (1:1000) (\#M7905, Sigma-Aldrich), mouse monoclonal anti-MYPT1(1:1000) (\#612165, BD Biosciences), rabbit polyclonal anti-phosphorylated MYPT1 (Thr ${ }^{853}$ ) (1:1000) (\#4563, CST), mouse monoclonal anti-smooth muscle-specific $\alpha$-actin ( $\alpha$ SMA) (1:1000) (\#A5228, Sigma-Aldrich), mouse monoclonal anti-glyceraldehyde 3-phosphate dehydrogenase (GAPDH) (1:1000) (\#016-25523, FUJIFILM-Wako Pure Chemical), and mouse monoclonal anti- $\beta$-actin (1:1000) (\#010-27841, FUJIFILM-Wako Pure Chemical). Membranes were then incubated with alkaline phosphatase-conjugated secondary antibodies, anti-rabbit immunoglobulin (Ig) G antibody (1:1000) (\#7054, CST) and anti-mouse IgG antibody (1:1000) (\#7056, CST) for $1 \mathrm{~h}$, and the protein bands were visualized by color reaction using nitro-blue tetrazolium/5-bromo-4-chloro3 -indolylphosphate p-toluidine (FUJIFILM Wako Pure Chemical) system. Protein band intensities were determined using Image Studio lite software (LI-COR Biosciences, Lincoln, NB, USA), normalized for amounts of the internal control GAPDH or $\beta$-actin and expressed as percentages of values in control cells.

\section{Statistical analysis}

Statistical analysis was performed with Graphpad Prism software version 8 . Data are presented as means \pm standard error of mean (SEM). Analysis between two groups was done with two-tailed unpaired Student's $t$-test. For comparison between multiple groups, one or two ways ANOVA followed by Bonferroni post hoc test was used 
unless stated otherwise. $p$ value $<0.05$ was considered to be statistically significant.

\section{Results \\ Decreased blood pressure in C2 $\alpha$ - and C2 $\beta$-double knockout mice}

To study the effects of genetic deletion of $\mathrm{C} 2 \alpha$ and $\mathrm{C} 2 \beta$ on blood pressure and vascular smooth muscle contraction, we employed smooth muscle-specific $\mathrm{C} 2 \alpha$ knockout $(\mathrm{C} 2 \alpha \mathrm{KO})$ mice, global $\mathrm{C} 2 \beta$-knockout $\left(\mathrm{C}^{2} \beta^{-1-}(\mathrm{C} 2 \beta \mathrm{KO})\right)$ mice, and double knockout (DKO) mice with smooth muscle-specific $\mathrm{C} 2 \alpha \mathrm{KO}$ and global $\mathrm{C} 2 \beta \mathrm{KO}$, which we described previously $[3,16]$. Smooth muscle-specific $\mathrm{C} 2 \alpha \mathrm{KO}$ mice were generated by mating $\mathrm{C} 2 \alpha^{\text {flox/flox }}$ and SM22 $\alpha-C r e$ transgenic mice. We confirmed that SM22 $\alpha$ promoter-driven Cre expression efficiently deleted the floxed sequence in the R26-tdTomato reporter construct, resulting in the expression of tdTomato protein in aortic smooth muscle layer which also expressed smooth muscle-specific myosin heavy chain isoform Mhc11, but not in the adventitial layer (Fig. 1a). The immunostaining of the aortic sections showed that $\mathrm{C} 2 \beta$ was expressed abundantly in the smooth muscle layer and slightly in the endothelium of wild-type mice but not of C2 $\beta \mathrm{KO}$ mice (Fig. 1b). In control C2 $\alpha$-floxed $\left(\mathrm{C} 2 \alpha^{\text {flox/flox }}\right)$ and $\mathrm{C} 2 \beta \mathrm{KO}$ mice, $\mathrm{C} 2 \alpha$ was expressed in both the endothelium and smooth muscle layer of the aorta, whereas $\mathrm{C} 2 \alpha$ expression was deficient in the smooth muscle layer but not the endothelium of smooth muscle-specific $\mathrm{C} 2 \alpha \mathrm{KO}$ mice (Fig. 1c). We performed morphological studies of the aorta and mesenteric artery in DKO and control mice using the immunostaining of the smooth musclespecific proteins Mhc11 and SM22 $\alpha$ and the endothelial marker CD31 (Fig. 2a, b). The medial smooth muscle and endothelial layers were similar in DKO and control mice, suggesting that the structure of the vasculature was not compromised in DKO mice.

Either $\mathrm{C} 2 \alpha \mathrm{KO}$ mice or $\mathrm{C} 2 \beta \mathrm{KO}$ mice showed no difference in systolic, diastolic or mean BP compared with control C2 $\alpha^{\text {flox/flox }}$ and $\mathrm{C} 2 \beta^{+/+}$mice, respectively (Fig. 3a, b). In contrast, DKO mice exhibited lower levels of systolic, diastolic and mean BP compared with control $\mathrm{C} 2 \alpha^{\text {flox/flox }}$ mice (Fig. 3c).

\section{Attenuated contraction of aortic rings and aortic smooth muscle cells from DKO mice}

We determined $\mathrm{NA}$ - and $\mathrm{KCl}$-induced contractile responses of aortic rings isolated from DKO and control mice. NA-induced dose-dependent contraction was markedly reduced in the aortic rings from DKO mice compared with control mice (Fig. 4a). KCl-induced contraction was also reduced in DKO mice compared with control mice (Fig. 4b).

We next determined contractile responses of MASM isolated from the aortae of control and $\mathrm{KO}$ mice. Cells were loaded with Fluo-8 to visualize cell shapes under a fluorescent microscope. The $\mathrm{Ca}^{2+}$ ionophore ionomycin (IMC) was employed as a stimulant because MASM lost the responsiveness to $\mathrm{KCl}$-membrane depolarization and receptor agonists including NA, serotonin and a thromboxane analogue during cell culture for isolation. Ionomycin induced marked contraction of MASM from control mice with an increase in cellular Fluo-8 fluorescence (Fig. 5). To quantify cell contraction, a reduction of the planar cell surface area was determined in each cell. C2 $\alpha \mathrm{KO}$ cells and $\mathrm{C} 2 \beta \mathrm{KO}$ cells exhibited the similar extent of IMC-induced contraction compared with each control group of cells (Fig. 5a, b). In contrast, DKO cells showed markedly reduced contraction compared with control MASMs (Fig. 5c). These findings indicate that either $\mathrm{C} 2 \alpha$ or $\mathrm{C} 2 \beta$ is required for contraction, i.e., $\mathrm{C} 2 \alpha$ and $\mathrm{C} 2 \beta$ are engaged in contraction of MASM in a redundant manner.

\section{Attenuated contraction of HASM deficient in both C2a and $\mathrm{C} 2 \beta$}

Because MASM were not suitable for further studies of $\mathrm{C} 2 \alpha$ and $\mathrm{C} 2 \beta$ actions due to limited yield of cells isolated by the enzymatic dispersion method, we took advantage of HASMs which were depleted of $\mathrm{C} 2 \alpha$ and $\mathrm{C} 2 \beta$ by transfection of the specific siRNAs. Both $C 2 \alpha-$ and $C 2 \beta-$ specific siRNAs effectively and specifically depleted the expression of respective proteins by $75-80 \%$ (Fig. 6a).

\footnotetext{
(See figure on next page.)

Fig. 1 Deletion of $C 2 a$ and $C 2 \beta$ in the aortic smooth muscle layer of knockout mice. a The expression of tdTomato and immunofluorescence staining of myosin heavy chain 11 (Mhc11) in the medial smooth muscle layer of the aorta in SM22a-Cre; R26-tdTomato reporter mice. Mhc11-positive cells express tdTomato protein. $\mathbf{b}$ Deletion of C2 $\beta$ in the medial smooth muscle layer and the endothelium of the aorta in C2 $a^{\text {flox } /}$ ${ }^{\text {flox }} \mathrm{C} 2 \beta^{-1-}$; SM22a-Cre mouse. The sections of the aortic wall were immunostained using anti-C2 $\beta$, anti-CD31 and anti-aSMA antibodies. The medial smooth muscle layer (SM) and the endothelium (E) were completely devoid of C2 $\beta$ expression in C2 $a^{\text {flox/flox }} \mathrm{C} 2 \beta^{-1-}$; SM22a-Cre mouse (lower right), differently from wild type (BL6) mouse (lower left). IEL internal elastic lamina, EEL external elastic lamina. c Marked reduction of C2a expression in the SM but not the $\mathrm{E}$ of the aorta in $\mathrm{C} 2 \mathrm{a}^{\text {flox/flox }} \mathrm{C} 2 \beta^{-1-} ; \mathrm{SM} 22 \mathrm{a}-\mathrm{Cre}$ mouse. The sections of the aortic wall were immunostained using anti-C2a, anti-CD31 and anti-aSMA antibodies. In $\mathbf{b}$ and $\mathbf{c}$, yellow arrowheads indicate endothelial deletion of C2 $\beta$ in $C 2 a^{\text {flox/flox }} \mathrm{C} 2 \beta^{-1-}$ mouse but not of $\mathrm{C} 2 a$

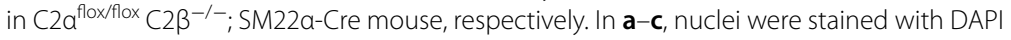




\section{a SM22a-Cre; R26-tdTomato aorta}
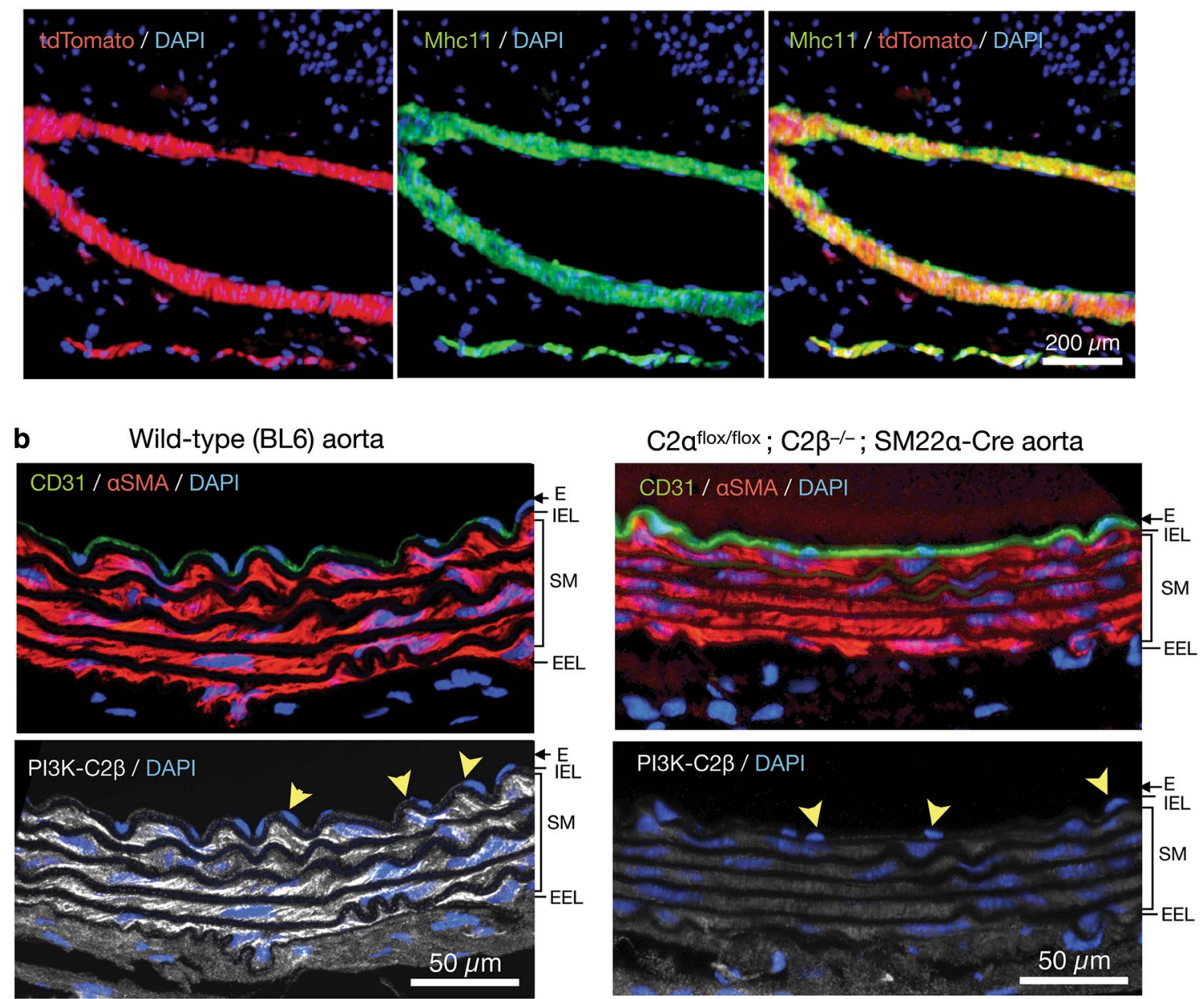

c

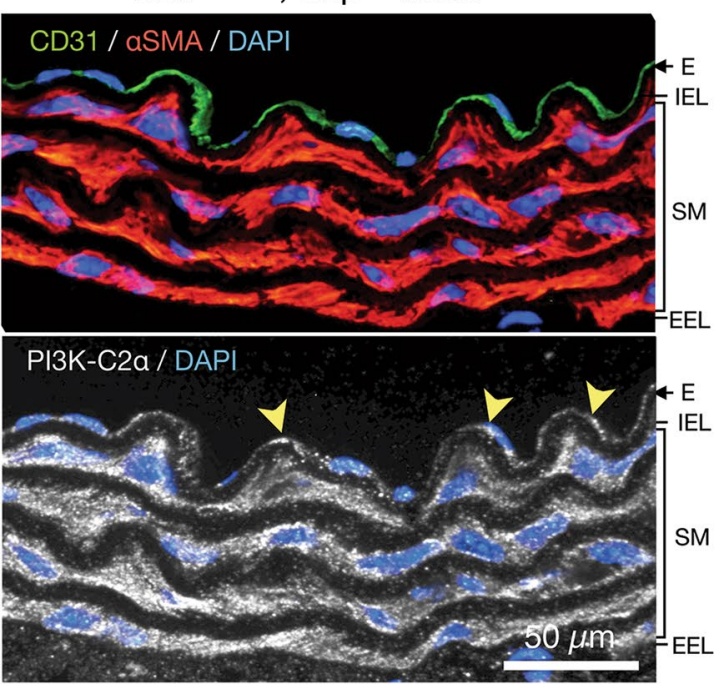

C2a flox/flox $; \mathrm{C}^{2} \beta^{-/-} ; \mathrm{SM} 22 \mathrm{a}-\mathrm{Cre}$ aorta

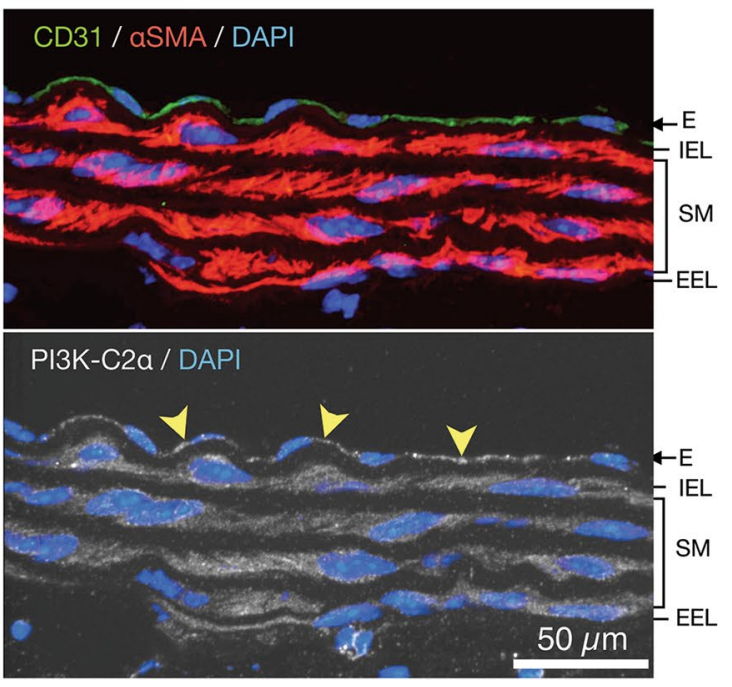



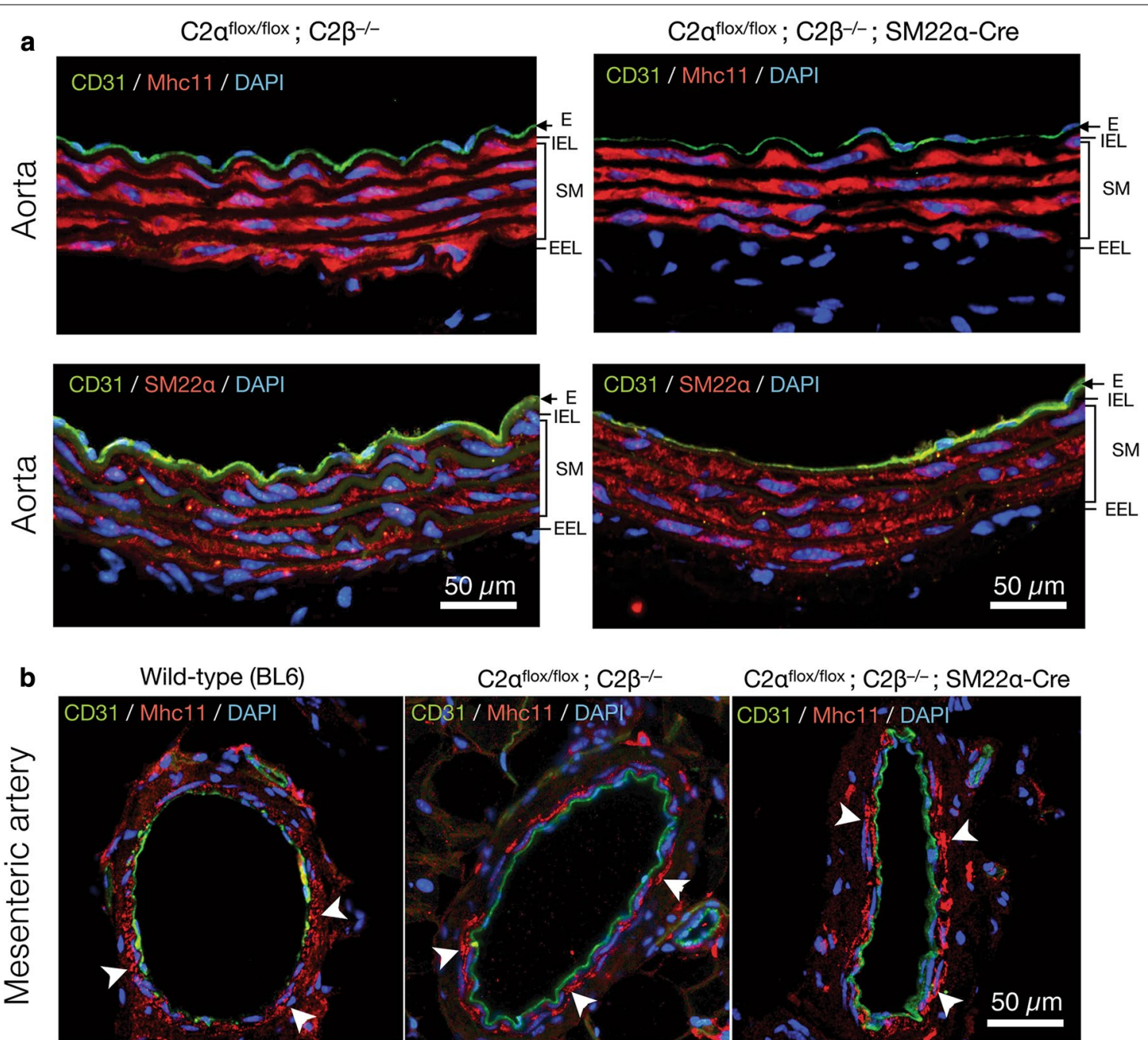

Fig. 2 Expression of the smooth muscle-specific proteins in the aorta and mesenteric artery of control and knockout mice. a Immunofluorescence staining of the smooth muscle-specific proteins Mhc1 1 and SM22a in the aorta of control (C2a flox/flox; $\left.\mathrm{C} 2 \beta^{-/-}\right)$and DKO (C2 $a^{\text {flox/flox}} ; \mathrm{C}_{2} \beta^{-1-}$; SM22a-Cre) mice. The SM layer was similarly stained by anti-Mhc1 1 and anti-SM22a antibodies. $\mathbf{b}$ Immunofluorescent staining of Mhc 11 in the mesenteric artery of wild-type (BL6) (left), $C 2 a^{\text {flox/flox }} \mathrm{C}_{2} \beta^{-1-}$ (middle), and C2 $\mathrm{a}^{\text {flox/flox }} \mathrm{C} 2 \beta^{-1-}$; SM22a-Cre mice (right). White arrowheads indicate similar expression of MhC1 1 in the SM. In $\mathbf{a}$ and $\mathbf{b}$, nuclei were stained with DAPI

The combination of $\mathrm{C} 2 \alpha$ - and $\mathrm{C} 2 \beta$-specific siRNAs efficiently inhibited the expression of both $C 2 \alpha$ and $C 2 \beta$. Control siRNA-transfected HASM contracted robustly in response to IMC (Fig. $6 \mathrm{~b}$ and Additional file 1: Video S1). Either singly $\mathrm{C} 2 \alpha$ - or $\mathrm{C} 2 \beta$-depleted cells showed the similar extents of contraction compared with control HASM (Additional file 2: Video S2 and Additional file 3: Video S3). In contrast, $\mathrm{C} 2 \alpha$ - or $\mathrm{C} 2 \beta$-doubly depleted HASM showed substantial attenuation of contraction compared with control and single $\mathrm{C} 2 \alpha$ - or $\mathrm{C} 2 \beta$-depleted cells (Additional file 4: Video S4). Thus, either $\mathrm{C} 2 \alpha$ or $\mathrm{C} 2 \beta$ is required for full contraction of HASM similarly to the responses of mouse aortic rings and MASM and, therefore, depletion of both $C 2 \alpha$ and $C 2 \beta$ severely impairs contraction.

\section{Attenuated phosphorylation of $M L C_{20}$ and MYPT1 in HASMs deficient in both $\mathrm{C} 2 \alpha$ and $\mathrm{C} 2 \beta$}

We explored the intracellular mechanisms for the diminished contraction of $C 2 \alpha$ - and C2 $\beta$-depleted HASM. Single depletion of $\mathrm{C} 2 \alpha$ or $\mathrm{C} 2 \beta$ or double depletion of both $\mathrm{C} 2 \alpha$ and $\mathrm{C} 2 \beta$ did not affect IMC-induced increases in the intracellular free $\mathrm{Ca}^{2+}$ concentration $\left(\left[\mathrm{Ca}^{2+}\right]_{\mathrm{i}}\right)$ as determined with Fluo-8 as $\mathrm{Ca}^{2+}$ indicator (Fig. 6c). Depletion of $\mathrm{C} 2 \alpha$ and $\mathrm{C} 2 \beta$ did not affect the protein expression of smooth muscle-specific myosin heavy chain isoform 

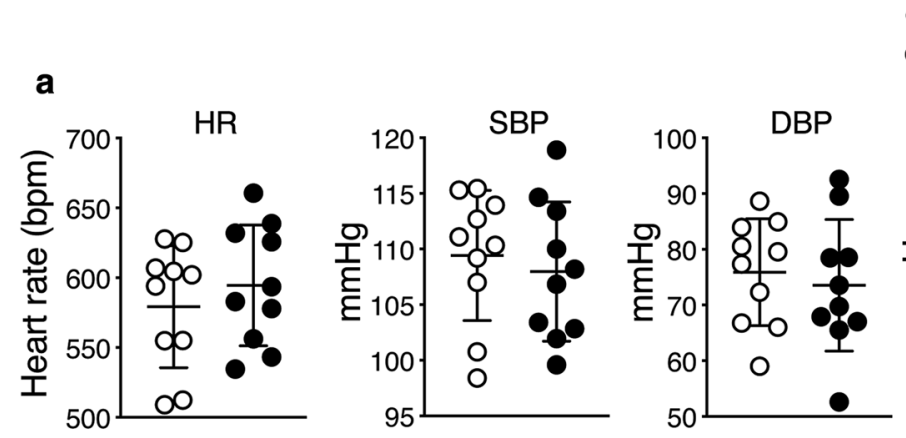

- $\mathrm{C} 2 \mathrm{a}^{\text {flox/flox }}$

- $\mathrm{C} 2 \mathrm{a}^{\text {flox/flox }} ; \mathrm{SM} 22 \alpha-\mathrm{Cre}$

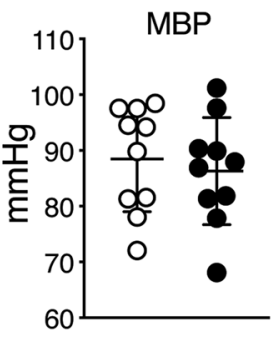

○ $\mathrm{C} 2 \beta^{+/+}$

- $\mathrm{C} 2 \beta^{-1-}$

$$
\text { b }
$$

HR
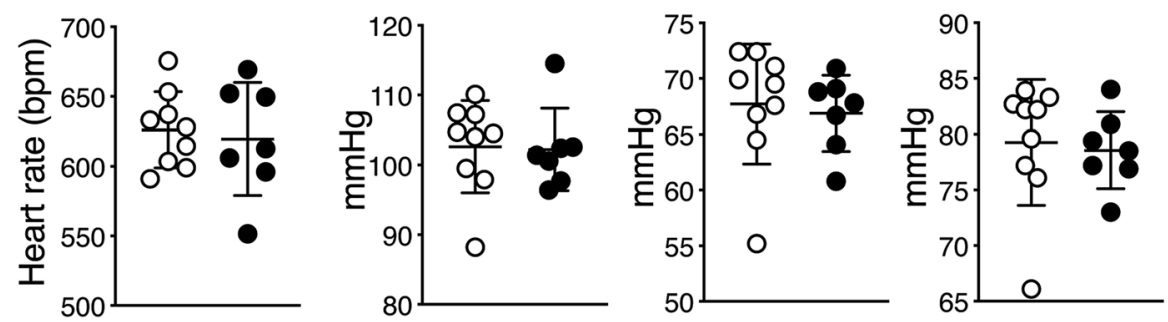

- $\mathrm{C} 2 \mathrm{a}^{\text {flox/flox }} \mathrm{C} 2 \beta^{-/-}$

- $\mathrm{C} 2 \mathrm{a}^{\text {flox/flox }} \mathrm{C} 2 \beta^{-1-} ; \mathrm{SM} 22 \alpha-$ Cre
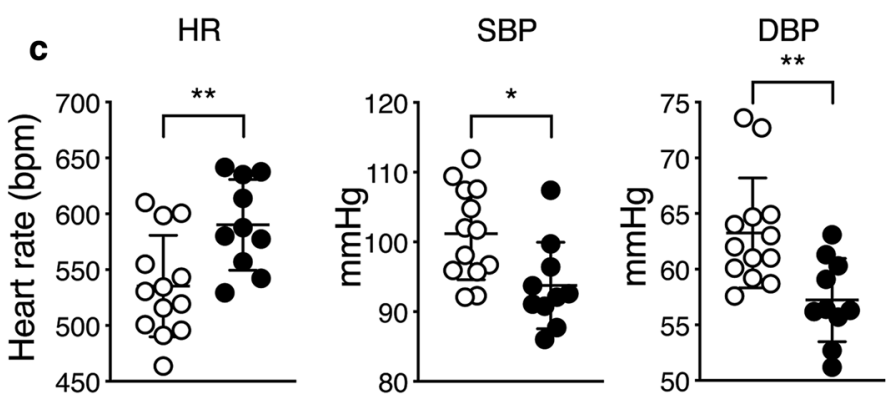

MBP

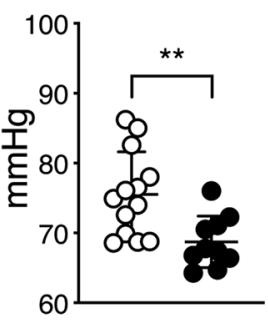

Fig. 3 Blood pressure is decreased in DKO mice. Heart rate (HR), systolic (SBP), diastolic (DBP) and mean (MBP) blood pressure in C2 $a^{\text {flox } / \text { flox }}(n=10)$ and C2 $a^{\text {flox/flox; }}$ SM22a-Cre mice $(n=10)(\mathbf{a})$, in wild-type $\left(C 2 \beta^{+/+}\right)(n=10)$ and C2 $\beta^{-/-}(n=9)$ mice $(\mathbf{b})$, and in C2 $a^{\text {flox/flox }} C 2 \beta^{-/-}(n=13)$ and C2 $a^{\text {flox } /}$ ${ }^{\text {flox }} \mathrm{C} 2 \beta^{-1-}$; SM22a-Cre $(n=10)$ mice (c). ${ }^{\star} p<0.05,{ }^{\star \star} p<0.01$

Mhc11, MLCK or MYPT1, but reduced the expression of $\mathrm{MLC}_{20}$ and $\alpha$ SMA in HASM (Fig. 7a). IMC induced time-dependent increases in mono $\left(\mathrm{Ser}^{19}\right)$ - and di $\left(\mathrm{Thr}^{18}\right.$, and $\mathrm{Ser}^{19}$ )-phosphorylation of $\mathrm{MLC}_{20}$ in HASM (Fig. 7b). Double knockdown of $\mathrm{C} 2 \alpha$ and $\mathrm{C} 2 \beta$ substantially reduced mono- and di-phosphorylation of $\mathrm{MLC}_{20}$ when evaluated as values corrected for total amount of $\mathrm{MLC}_{20}$. IMC also increased phosphorylation of MYPT1 (Fig. 7c), suggesting that IMC suppressed MLCP activity. Moreover, the Rho kinase inhibitor Y27632 substantially inhibited not only IMC-induced contraction (Fig. 6b), but also mono- and di-phosphorylation of $\mathrm{MLC}_{20}$ and MYPT1 phosphorylation in HASM (Fig. 7c), suggesting that Rho kinase was involved in IMC-induced MLCP inhibition, $\mathrm{MLC}_{20}$ phosphorylation and contraction.

\section{Subcellular localization of $\mathrm{C} 2 \alpha$ and $\mathrm{C} 2 \beta$ in HASM}

To try to understand the role of $\mathrm{C} 2 \alpha$ and $\mathrm{C} 2 \beta$ in the contractile signaling in more depth, we studied the subcellular localization of $\mathrm{C} 2 \alpha$ and $\mathrm{C} 2 \beta$ in HASMs. We cotransfected HASMs with GFP-tagged C2 $\alpha$ (GFP-C $2 \alpha)$ and mCherry-tagged $\mathrm{C} 2 \beta$ (mCherry-C2 $\beta$ ) and observed 

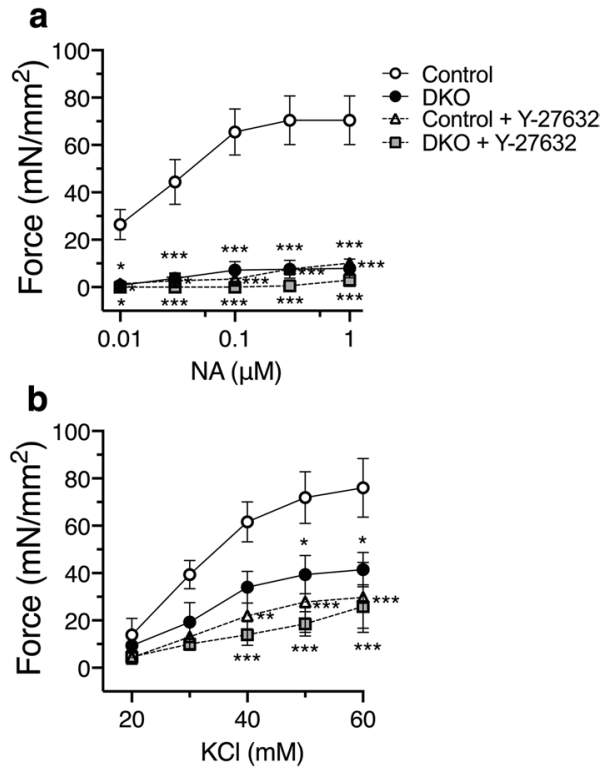

Fig. 4 Attenuated contraction of the aortic rings from DKO mice. a Dose-dependent noradrenaline (NA)- and $\mathrm{KCl} \mathbf{b}$-induced isometric contraction of the aortic rings from $\mathrm{C} 2 \mathrm{a}^{\text {flox/flox }} \mathrm{C} 2 \mathrm{\beta}^{-/-}$(control) and DKO mice with and without the Rho kinase inhibitor Y-27632 (10 $\mu \mathrm{M})$ was determined ( $n=3$ per each group). ${ }^{\star} p<0.05,{ }^{\star}{ }^{\star} p<0.01$ and $\star \star \star p<0.001$ compared with control mouse rings

cells by confocal microscopy coupled with super-resolution radial fluctuation (SRRF-Stream) mode. We found that GFP-C2 $\alpha$ was distributed diffusely as fine puncta and as coarse puncta locally in the perinuclear region with some signals at or near the plasma membrane in HASMs (Fig. 8a, upper left and lower views). mCherry$\mathrm{C} 2 \beta$ was distributed in a fibrillary pattern in the peripheral cytoplasmic region close to the plasma membrane and in perinuclear coarse puncta with some co-localization with GFP-C2 $\alpha$ (Fig. 8a, upper right and lower views). In the perinuclear coarse puncta and the peripheral fibrillary localization, mCherry-C2 $\beta$ was co-localized with GFP-C2 $\alpha$ (Fig. $8 \mathrm{a}$, upper right and lower right view). The subcellular distribution of GFP-C $2 \alpha$ and mCherry-C2 $\beta$ was similar to that in human umbilical vein endothelial cells [5]. We previously observed the close co-localization of GFP-C $2 \alpha$ and clathrin in human endothelial cells [5]. We found the similar co-localization of GFP-C2 $\alpha$ and clathrin in HASMs (Fig. 8b). mCherry-C2 $\beta$ was also colocalized with clathrin, but less frequently compared with GFP-C $2 \alpha$. This finding was also similar to that in human endothelial cells.

\section{Attenuated Rho activation in HASM deficient in both $\mathrm{C} 2 a$ and C2 $\beta$}

We determined IMC-induced Rho activation in HASMs, using a FRET imaging technique. Both
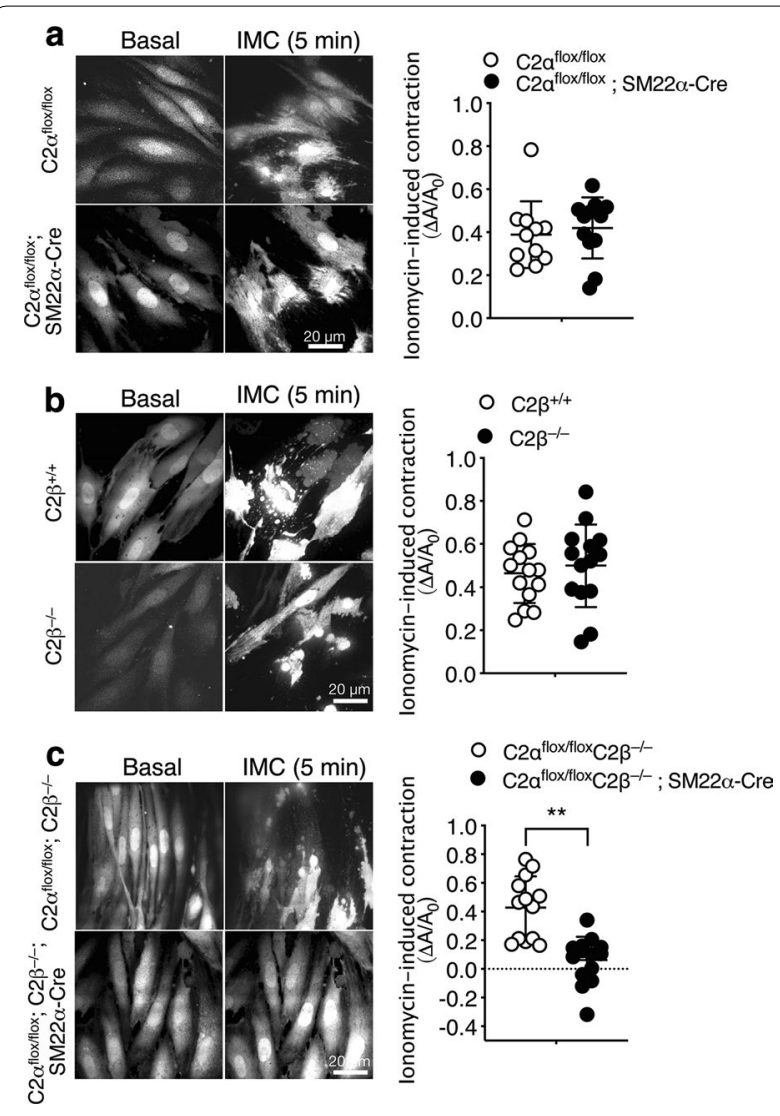

Fig. 5 Attenuated contraction of MASM isolated from DKO mice. Fluo-8-loaded MASM were stimulated with $0.3 \mu \mathrm{M}$ ionomycin. A difference in the planar cell surface area before and after the addition of ionomycin $\left(\triangle A / A_{0}\right)$ was determined in each cell and compared in C2a flox/flox $(n=11)$ and C2 $a^{\text {flox/flox; }}$ SM22a-Cre mice $(n=12)(\mathbf{a})$, in wild-type $\left(C 2 \beta^{+/+}\right)(n=14)$ and $C 2 \beta^{-/-}(n=14)$ mice $(\mathbf{b})$, and in C2 $a^{\text {flox/flox }} \mathrm{C} 2 \beta^{-/-}(n=13)$ and C2a flox/flox $C 2 \beta^{-/-} ;$SM22a-Cre $(n=14)$ mice (c). Representative images of cells (left) and quantified data (right) are shown. ${ }^{\star} p<0.01$

IMC- and ET-1-induced Rho activation detectable within 1 min mainly in the intracellular compartment in control HASMs, and it persisted for at least $10 \mathrm{~min}$ of the observation time period (Fig. 9a, b, and Additional file 5: Video S5 and Additional file 6: Video S6). In contrast, in cells deficient in both $\mathrm{C} 2 \alpha$ and $\mathrm{C} 2 \beta, \mathrm{IMC}$ - and ET-1-induced Rho activation was markedly inhibited with only slight activation observed in the intracellular compartment at 5 to $10 \mathrm{~min}$ (Fig. 9a, b, and Additional file 5: Video S5 and Additional file 6: Video S6). In control cells, Rho-FRET signals were partially co-localized with the early endosome marker Rab5. In cells deficient in both $C 2 \alpha$ and $C 2 \beta$, FRET signals were greatly attenuated in both Rab5-positive and negative intracellular sites (Fig. 9c). These observations suggested that $\mathrm{C} 2 \alpha$ and $\mathrm{C} 2 \beta$ were involved in Rho activation in the intracellular compartment. 


\section{Discussion}

In this study, we demonstrated that class II PI3K C2 $\alpha$ and $\mathrm{C} 2 \beta$ have the essential redundant role in the blood pressure regulation and vascular smooth muscle contraction. Mice that have both smooth muscle-specific $\mathrm{C} 2 \alpha$ deletion and global $\mathrm{C} 2 \beta$ deletion are not lethal and therefore allowed us to evaluate the role of $\mathrm{C} 2 \alpha$ and $\mathrm{C} 2 \beta$ in blood pressure regulation. Double $\mathrm{KO}$ of $\mathrm{C} 2 \alpha$ and $\mathrm{C} 2 \beta$ but no single $\mathrm{KO}$ of either gene resulted in a decrease in arterial blood pressure, indicating that at least one isoform of $\mathrm{C} 2 \alpha$ and $\mathrm{C} 2 \beta$ is necessary for the maintenance of blood pressure. The diminished contractile capacity of vascular smooth muscle from DKO mice suggested that attenuated vascular smooth muscle contraction was involved in hypotension in DKO mice. Moreover, the attenuation of Rho activation and resultant Rho kinase-dependent MLCP inhibition, but not of $\mathrm{Ca}^{2+}$ mobilization, was suggested to underlie attenuated vascular contraction and decreased blood pressure in DKO mice. These findings, together with our recent observations of the essential redundant role of $\mathrm{C} 2 \alpha$ and $\mathrm{C} 2 \beta$ in uterine smooth muscle contraction and parturition [17], point to the importance of $\mathrm{C} 2 \alpha$ and $\mathrm{C} 2 \beta$ for activation of Rho and Rho kinase pathway in smooth muscle contraction in mice.

Vascular smooth muscle tone is a major determinant of the blood pressure and directly regulated by the contraction and relaxation state of vascular smooth muscle, which are under the control of various vasoconstrictors and vasodilators, sympathetic nerve activity, and mechanical stress [20-22]. The contractile responses of DKO mouse-derived aortic rings to NA and membrane depolarization were substantially reduced compared with aortic rings from control mice. Smooth muscle contraction is mediated by the two major signaling pathways of $\mathrm{Ca}^{2+}$-dependent MLCK activation $\left(\mathrm{Ca}^{2+}\right.$-MLCK pathway) and Rho- and Rho kinase-dependent MLCP inhibition (Rho-MLCP pathway) [23-26]. The increase in the $\left[\mathrm{Ca}^{2+}\right]_{\mathrm{i}}$ activates $\mathrm{Ca}^{2+} /$ calmodulin-dependent MLCK, leading to $\mathrm{MLC}_{20}$ phosphorylation, and Rho activates its effector Rho kinase, resulting in inhibition of MLCP by phosphorylating the myosin-targeting subunit MYPT1 of MLCP. Rho-MLCP pathway as well as $\mathrm{Ca}^{2+}$-MLCK pathway coordinately and effectively increase $\mathrm{MLC}_{20}$ phosphorylation, thus playing a critical role in contraction induced by various agonists including NA, endothelin-1 and thromboxane A2. We and others previously showed that an increase in $\left[\mathrm{Ca}^{2+}\right]_{\mathrm{i}}$ induced by membrane depolarization and $\mathrm{a} \mathrm{Ca}^{2+}$ ionophore also resulted in the activation of Rho-MLCP pathway in smooth muscle [27, $28]$. In $C 2 \alpha$ - and $C 2 \beta$-dually deficient vascular smooth muscle cells, the activity of Rho pathway but not $\mathrm{Ca}^{2+}$ pathway was attenuated compared with control cells, as evaluated with the FRET imaging of Rho activation and phosphorylation status of MYPT1. Therefore, it is likely that the attenuation of Rho signaling resulted in a higher MLCP activity, leading to reductions of $\mathrm{MLC}_{20}$ phosphorylation and contraction in $\mathrm{C} 2 \alpha$ - and $\mathrm{C} 2 \beta$-deficient vascular smooth muscle cells compared with control cells. We observed the reduced expression of $M_{20}$ and $\alpha$ SMA in HASM with either $\mathrm{C} 2 \beta$ single deficiency or $\mathrm{C} 2 \alpha / \mathrm{C} 2 \beta$ double deficiency. It is unknown how $\mathrm{C} 2 \beta$ and $\mathrm{C} 2 \alpha / \mathrm{C} 2 \beta$ deficiency resulted in the downregulation of the smooth muscle-specific proteins and remains to be clarified. However, it is unlikely that the reduced expression of $\mathrm{MLC}_{20}$ and $\alpha \mathrm{SMA}$ could be involved in the attenuation of contraction because single $\mathrm{C} 2 \beta$ depletion failed to inhibit contraction despite the reductions of $\mathrm{MLC}_{20}$ and $\alpha$ SMA expression.

We found in the present study that the $\mathrm{Ca}^{2+}$-ionophore ionomycin and endothelin-1-induced vigorous Rho activation mainly in the intracellular compartment of vascular smooth muscle cells. The intracellular localization of Rho activation site was consistent with our previous observations in mouse uterine smooth muscle cells [17] and human vascular endothelial cells [3], and reports by others in other types of cells [29-32]. Our study suggested that at least a part of the Rho activation sites was Rab5-positive structures, i.e., early endosomes.

The present study clearly showed that $\mathrm{C} 2 \alpha$ and $\mathrm{C} 2 \beta$ were required for Rho activation in the intracellular compartment in vascular smooth muscle cells. How are $\mathrm{C} 2 \alpha$ and $\mathrm{C} 2 \beta$ engaged in Rho activation at the early endosomes and other intracellular structures? Previous studies [3, 30-32] showed that $\mathrm{C} 2 \alpha$ is preferentially localized to clathrin-coated pits and vesicles and plays an indispensable role in clathrin-dependent endocytosis.

\footnotetext{
(See figure on next page.)

Fig. 6 Attenuated contraction of C2a- and C2 $\beta$-depleted HASM. a Knockdown of C2a and C2 $\beta$ proteins in HASM by the specific siRNAs. HASMs were transfected with control-, C2 $\alpha$ - and C2 $\beta$-siRNAs and subjected to Western blot analyses for C2a and C2 $\beta$ protein expression. Left, Western blotting. Middle and right panels, quantified data of $\mathrm{C} 2 \mathrm{a}$ and $\mathrm{C} 2 \beta$ protein expression. $\mathbf{b}$ Attenuated contraction of C2a- and C2 $\beta$-double depleted HASM. IMC (0.3 $\mu \mathrm{M})$-induced contraction was determined as in Fig. 5. A portion of control siRNA-transfected HASM were pretreated or unpretreated with Y-27632 (10 $\mu \mathrm{M})$ for $5 \mathrm{~min}$ and stimulated with ionomycin for $10 \mathrm{~min}$. Representative images of cells (left) and quantified data (right) are shown. ${ }^{\star} p<0.05$ and ${ }^{\star \star \star} p<0.001$ in the indicated comparisons. $\mathbf{c}$ No difference in ionomycin-induced increases in the [Ca $\left.{ }^{2+}\right]_{i}$ in HASM transfected with control-, $C 2 a$ - and $C 2 \beta$-siRNAs. Left, time-dependent changes in the $\left[\mathrm{Ca}^{2+}\right]_{\mathrm{i}}$ in ionomycin-stimulated cells. Right, quantified data of the peak response of the $\left[\mathrm{Ca}^{2+}\right]_{\mathrm{i}}$
} 


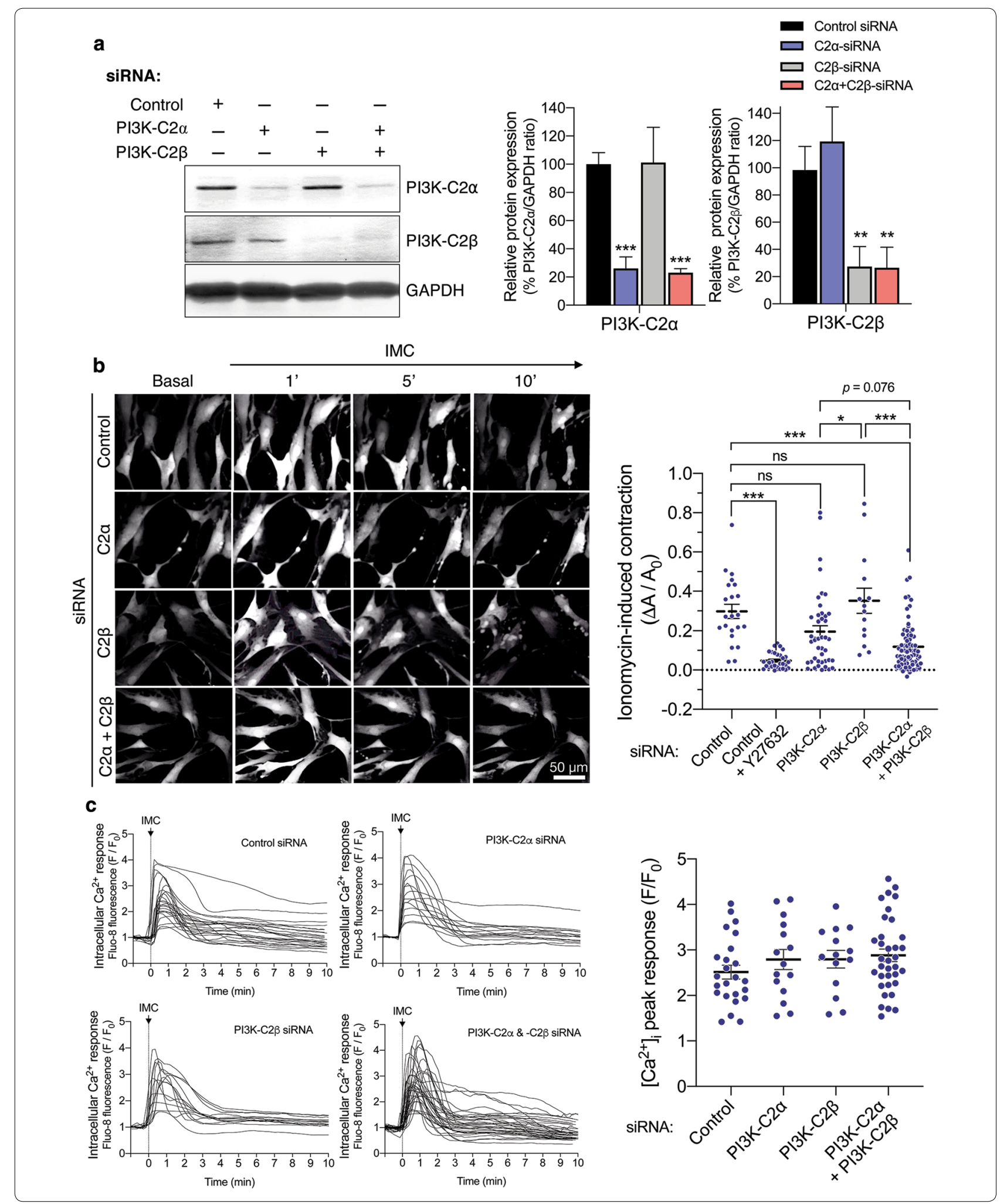




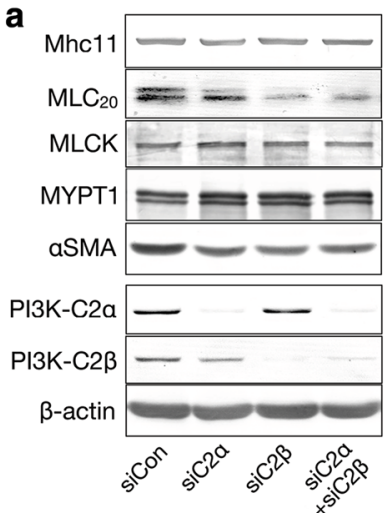

\section{b}

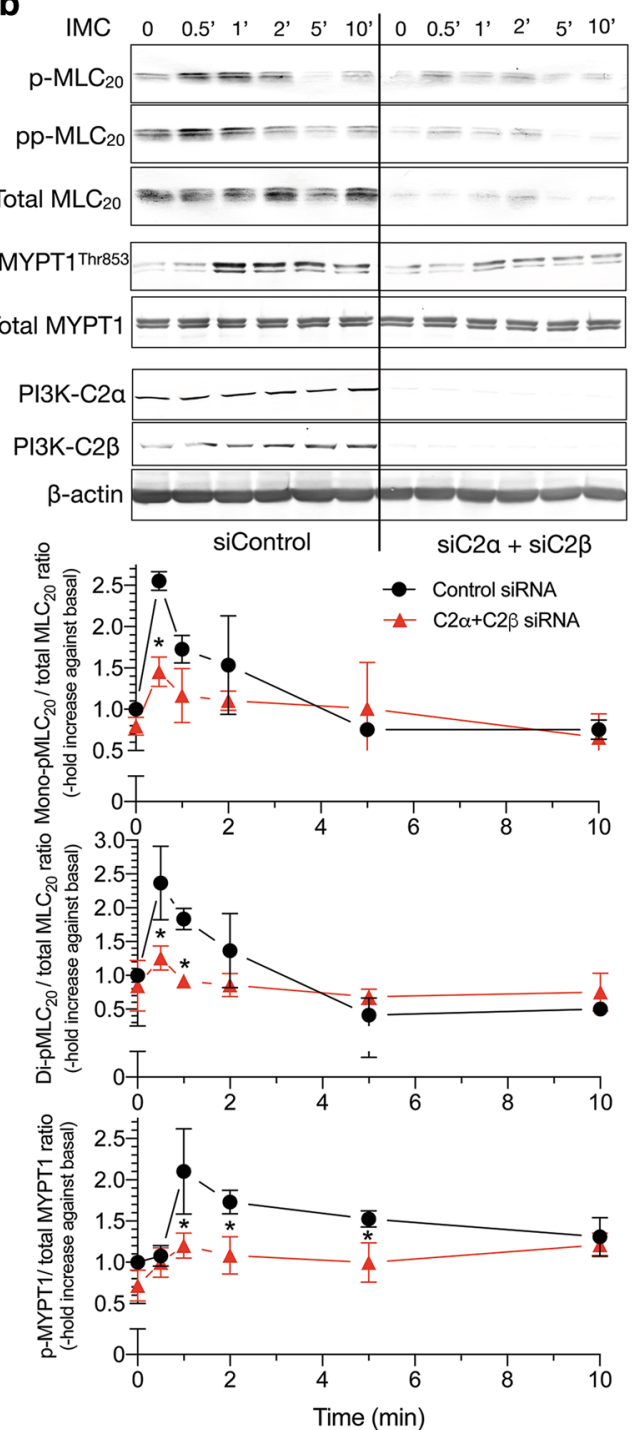

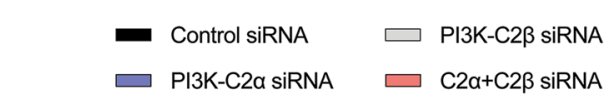

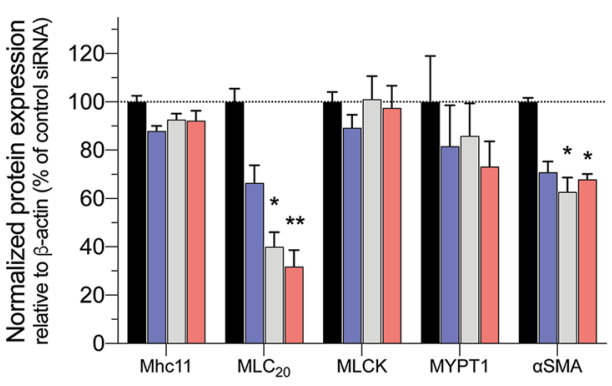

C

$\mathrm{IMC}--++--\mid--++-$

$\mathrm{ET}-1-{ }_{-}-++\infty-\infty$

Y-27632 - + - + + - + + +

$\mathrm{p}-\mathrm{MLC}_{20} \longrightarrow=$

$\mathrm{pp}-\mathrm{MLC}_{20} \longrightarrow-\ldots$

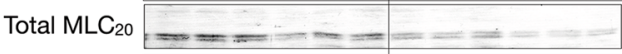

p-MYPT1Thr853 $=\Longrightarrow=-$

Total MYPT1 $=\approx= \pm=\equiv=$

$\beta$-actin
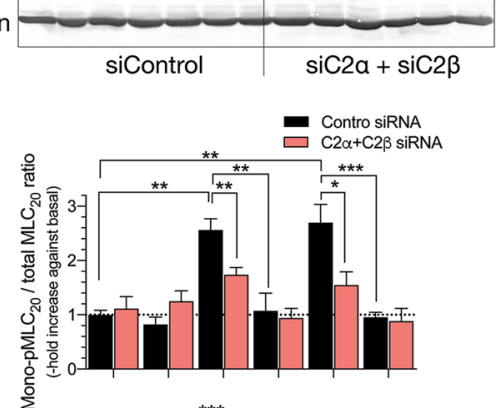

$\sum$ ****
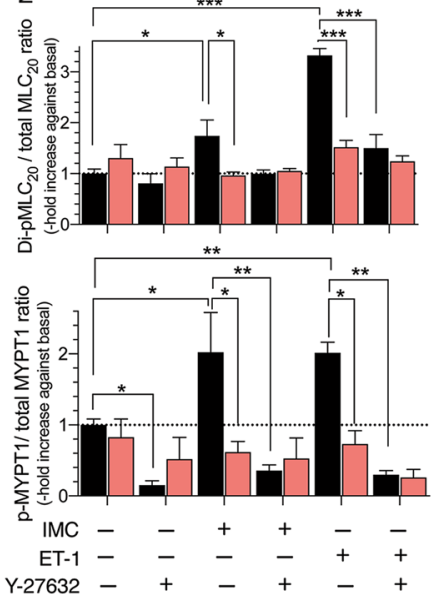

Fig. 7 Attenuated phosphorylation of MLC 20 and MYPT1 in C2 $\alpha$ - and C2 $\beta$-depleted HASM. a Effects of C2 $a$ and $C 2 \beta$ knockdown on the expression of smooth muscle-specific proteins in HASM. Cells were transfected with control-, C2a- and C2 $\beta$-siRNAs and subjected to Western blot analyses. Left, Western blots. Middle and right panels, quantified data of Mhc11, MLC 20 , MLCK, MYPT1 and aSMA. b Attenuated mono- and di-phosphorylation of $\mathrm{MLC}_{20}$ and phosphorylation of MYPT1 in C2a- and C2 $\beta$-double depleted HASM. HASM were transfected with control-, C2a- and C2 $\beta$-siRNAs and stimulated with $0.3 \mu \mathrm{M}$ ionomycin for $10 \mathrm{~min} .{ }^{\star} p<0.05$ compared with control siRNA-transfected cells. $\mathbf{c}$ Effects of ROCK inhibitor Y-27632 on mono- and di-phosphorylation of $\mathrm{MLC}_{20}$ and phosphorylation of MYPT1 in C2 $a$ - and C2 $\beta$-double depleted HASM. ${ }^{\star} p<0.05$, $\star \star p<0.01$ and ${ }^{\star \star \star} p<0.001$ in the indicated comparisons 
a
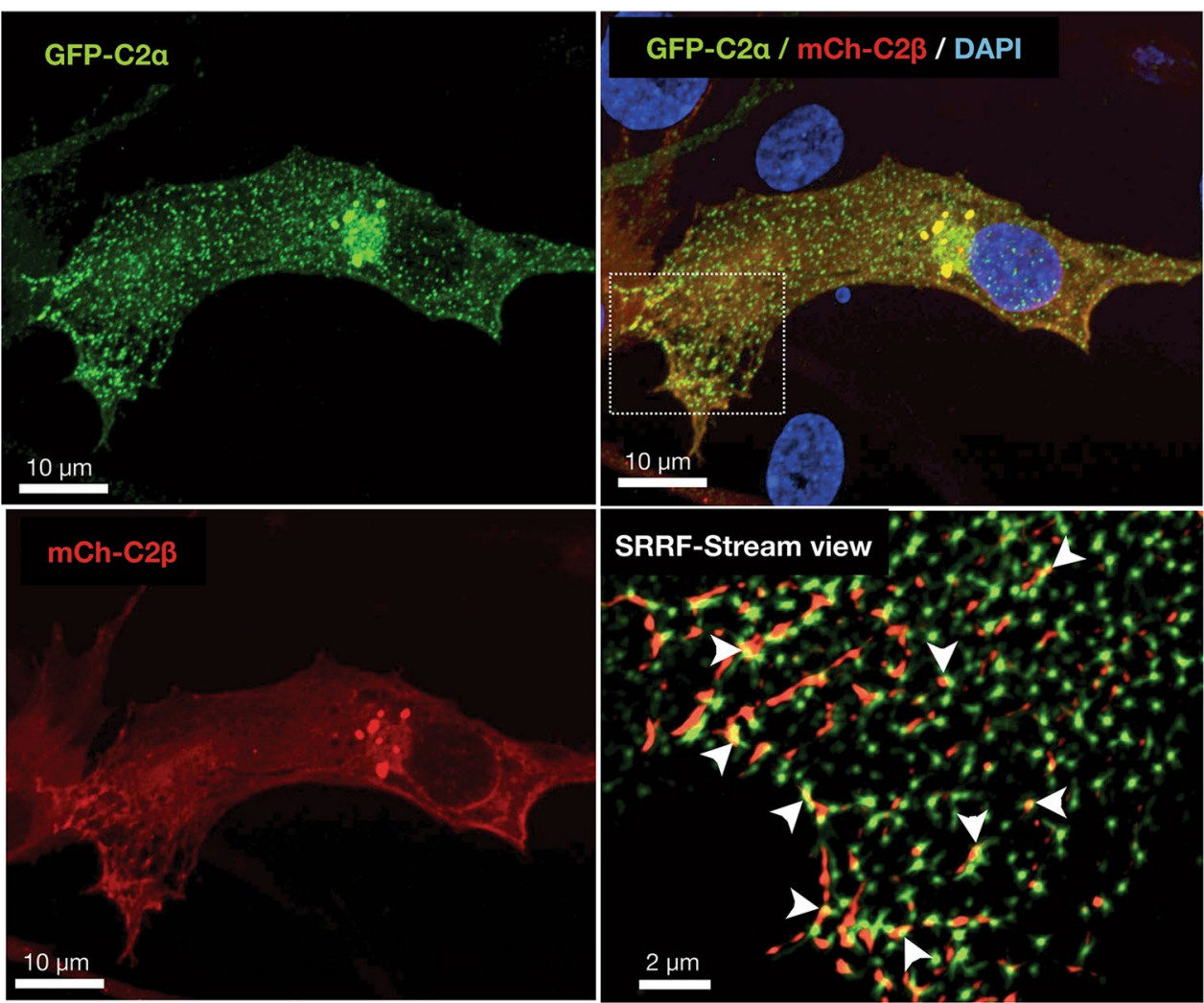

b
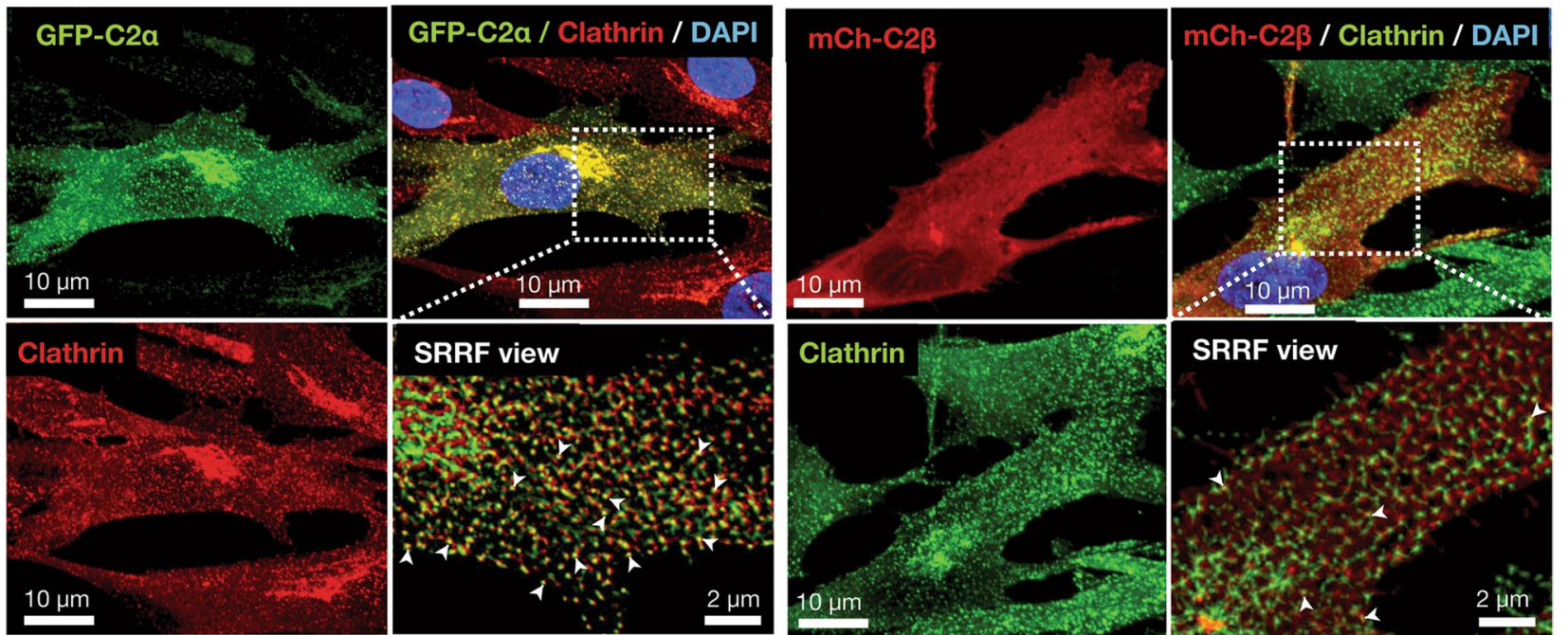

Fig. 8 Subcellular distribution of C2a and C2 $\beta$ in HASM. a Confocal images of subcellular distribution of GFP-C2a and mCherry-C2 $\beta$. Cells were co-transfected with the expression vectors for GFP-C2 $\alpha$ and $m$ Cherry-C2 $\beta$. GFP-C2 $\alpha$ is distributed at diffuse fine puncta and perinuclear coarse puncta. $m C h e r r y-C 2 \beta$ ( $m C h-C 2 \beta$ ) is distributed at perinuclear coarse puncta and plasma membrane. $m C h e r r y-C 2 \beta$ is also distributed diffusely in the mesh-like pattern with some co-localization with GFP-C2a (arrowheads in the lower right panel). $\mathbf{b}$ Co-localization of GFP-C2 $\alpha$ and mCherry-C2 $\beta$ with clathrin. Cells were co-transfected with the expression vectors of GFP-C2 $\alpha$ and mCherry-C2 $\beta$, and subjected to anti-clathrin heavy chain immunofluorescence staining. Nuclei were stained with DAPI. PI3K-C2 $a$ and PI3K-C2 $\beta$ were co-localized with clathrin heavy chain diffusely and at the perinuclear region although the co-localization of PI3K-C2 $\beta$ and clathrin heavy chain was less frequent 
$\mathrm{C} 2 \alpha$ mainly produces $\mathrm{PI}(3,4) \mathrm{P}_{2}$ [33-37] and recruits $\mathrm{PI}(3,4) \mathrm{P}_{2}$-binding domain-possessing proteins including SNX9, thus facilitating growth and maturation of clathrin-coated pits and their conversion into clathrin-coated vesicles. A functional role and intracellular localization of $\mathrm{C} 2 \beta$ was poorly understood compared with $\mathrm{C} 2 \alpha$. We recently demonstrated that $\mathrm{C} 2 \beta$ was localized at the focal filamentous actin (actin patches) in the peripheral cytoplasmic regions and clathrin-coated pits and vesicles in vascular endothelial cells and that $C 2 \beta$ as well as $\mathrm{C} 2 \alpha$ were necessary for clathrin-dependent fluid-phase endocytosis [5]. The present study showed that vascular smooth muscle cells exhibited the similar intracellular distribution of $\mathrm{C} 2 \beta$ to that in endothelial cells. Activation of Rho is mediated by a guanine nucleotideexchange factor (GEF) [38]. Therefore, a GEF is likely recruited to early endosomes and other intracellular structures in stimulated vascular smooth muscle cells. In the case of ET-1-stimulated vascular smooth muscle cells, it could be possible that class II PI3K might be necessary for the endocytosis of ET-1-bound receptor into the early endosomes and that the endocytosed receptor, in turn, might recruit a GEF via the heterotrimeric $\mathrm{G}$ protein $\mathrm{G}_{12 / 13}$ to result in Rho activation. When vascular smooth muscle cells are stimulated with IMC, a $\mathrm{Ca}^{2+}$-induced Rho activation mechanism operates [12, 27]. The $\mathrm{Ca}^{2+}$-induced Rho activation may be mediated by a particular type of GEF and the recruitment of the particular GEF may require a process of endocytosis of the GEF molecule itself or a regulatory molecule of the GEF [39]. These endocytic processes may be dependent on PI3K-C $2 \alpha$ and PI3K-C2 $\beta$. Further studies are required for defining the exact role of $C 2 \alpha$ and $C 2 \beta$ in the intracellular Rho activation.

Our previous studies showed that siRNA-mediated specific knockdown of only $\mathrm{C} 2 \alpha$-inhibited contraction of vascular smooth muscle cells derived from rat aortae [12, 13]. In contrast, the present study showed that knockdown of $\mathrm{C} 2 \alpha$ alone was not enough to completely inhibit contraction of mouse and human vascular smooth muscle cells, which may suggest that $C 2 \beta$ can compensate for a defect caused by $\mathrm{C} 2 \alpha$ deficiency in mouse and human vascular smooth muscle cells; $\mathrm{C} 2 \beta$ may be able to compensate for insufficient $\mathrm{PI}(3,4) \mathrm{P}_{2}$ production due to $\mathrm{C} 2 \alpha$ depletion in clathrin-coated pits and vesicles and other intracellular sites in mouse and human, but not rat, vascular smooth muscle cells. It is unknown at present whether the expression levels of $\mathrm{C} 2 \beta$ or differences in the subcellular localization of $\mathrm{C} 2 \beta$ could bring about the species difference in $\mathrm{C} 2 \alpha$ - and $\mathrm{C} 2 \beta$-dependence of vascular smooth muscle contraction. The exact molecular mechanisms for the species-specific dependence on $\mathrm{C} 2 \alpha$ and $\mathrm{C} 2 \beta$ of vascular smooth muscle contraction remain to be clarified.

Because the RhoA-Rho kinase-MLCP pathway is one of the major contractile mechanism in vascular smooth muscle contraction $[23,24,26]$, the novel role of $\mathrm{C} 2 \alpha$ and C2 $\beta$ in Rho-Rho kinase-MLCP pathway may provide some insight about understanding the pathophysiology and development of new therapies for cardiovascular diseases including hypertension and vasospasms. For example, a class II PI3K inhibitor, which inhibits Rho activation and thereby stimulates MLCP in vascular smooth muscle, may be a candidate for developing new anti-hypertensive and spasmolytic agents. Better understanding of the $\mathrm{C} 2 \alpha$ and $C 2 \beta$ actions at the cellular and molecular levels is required to unravel the pathophysiological role of human class II PI3K.

\section{Conclusions}

The present study showed the importance of $\mathrm{C} 2 \alpha$ and $\mathrm{C} 2 \beta$ in the regulation of the Rho-Rho kinase-MLCP pathway and contraction in vascular smooth muscle and blood pressure regulation. $\mathrm{C} 2 \alpha$ and $\mathrm{C} 2 \beta$ are required for $\mathrm{Ca}^{2+}$ - and receptor agonist-elicited Rho activation in the intracellular compartment. The role of $\mathrm{C} 2 \alpha$ and $\mathrm{C} 2 \beta$ is essential for vascular smooth muscle contraction, but compensatory for deficiency of each other. Further study is required to reveal the exact mechanism of $\mathrm{C} 2 \alpha-$ and $\mathrm{C} 2 \beta$-dependent Rho activation in vascular smooth muscle.

\footnotetext{
(See figure on next page.)

Fig. 9 FRET imaging of attenuated Rho activation in C2 $\alpha$ - and C2 $\beta$-depleted HASM. a Effects of C2 $a$ and C2 $\beta$ knockdown on the expression of

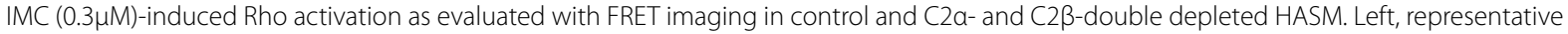
images. Right, quantified data of time-dependent Rho-FRET signals. b Effects of C2a and C2 $\beta$ knockdown on ET-1 (1 $\mu$ M)-induced Rho activation as evaluated with FRET imaging in control and C2a- and C2 $\beta$-double depleted HASM. Left, representative images. Right, quantified data of time-dependent Rho-FRET signals. c Partial co-localization of RhoA-FRET signals with the early endosome marker Rab5. Cells were transfected with BFP-Rab5 expression vector and the co-localization of RhoA-FRET signals and BFP-Rab5 was determined
} 


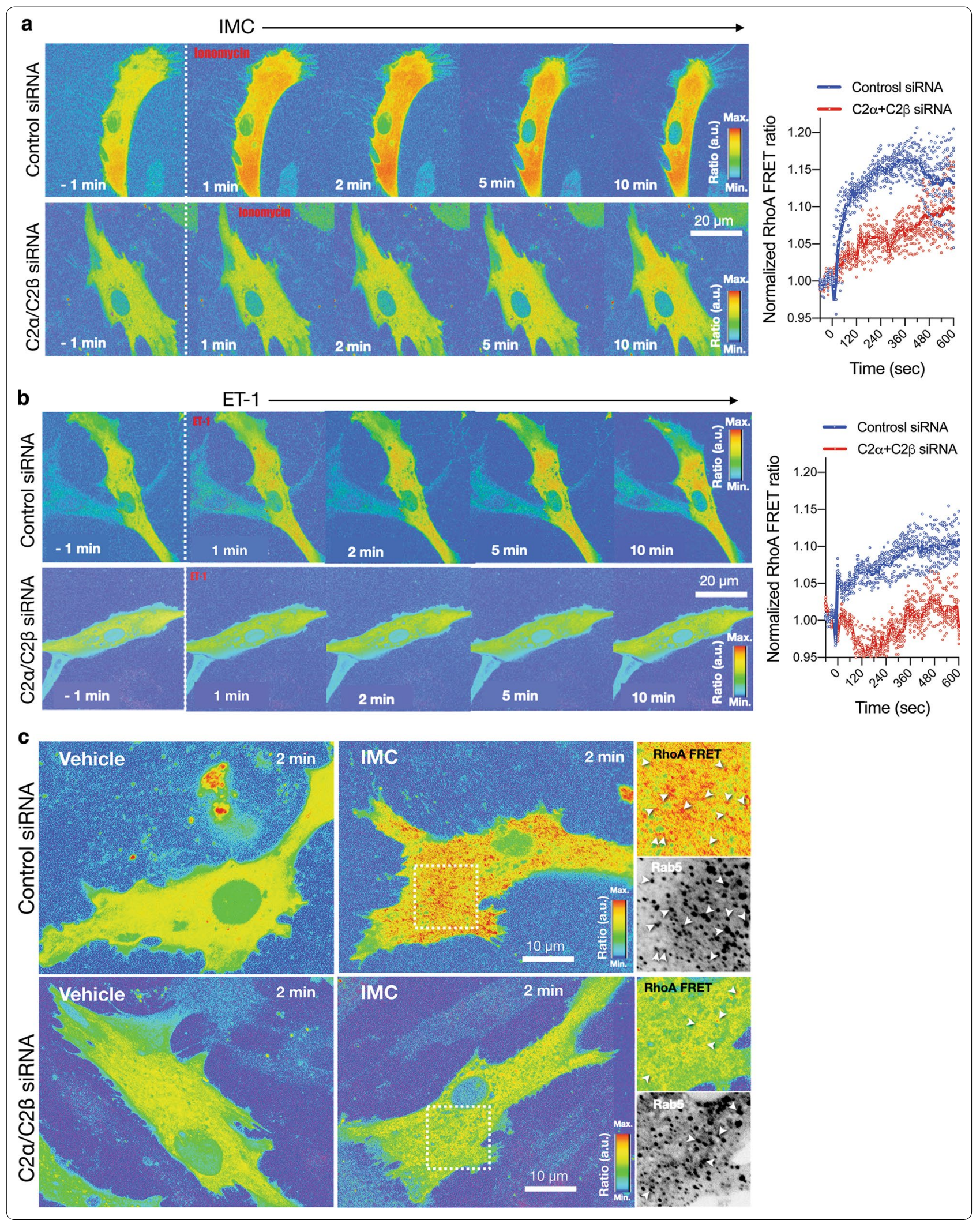




\section{Supplementary information}

Supplementary information accompanies this paper at https://doi. org/10.1186/s12576-020-00745-2.

Additional file 1: Video S1. The time-lapse imaging of ionomycininduced $\left[\mathrm{Ca}^{2+}\right]_{i}$ response and contraction of control siRNA-transfected HASM. Control siRNA-transfected, the fluorescent $\mathrm{Ca}^{2+}$ indicator fluo-8 loaded HASM cells were stimulated with ionomycin $(0.3 \mu \mathrm{M})$ at $1 \mathrm{~min}$, and contractile responses and changes in $\left[\mathrm{Ca}^{2+}\right]_{i}$ response were continuously monitored for 10 min (10-s intervals).

Additional file 2: Video S2. The time-lapse imaging of ionomycininduced $\left[\mathrm{Ca}^{2+}\right]_{i}$ response and contraction of PI3K-C2a siRNA-transfected HASM. PI3K-C2a specific siRNA-transfected, the fluorescent $\mathrm{Ca}^{2+}$ indicator fluo-8 loaded HASM cells were stimulated with ionomycin $(0.3 \mu \mathrm{M})$ at $1 \mathrm{~min}$, and contractile responses and changes in $\left[\mathrm{Ca}^{2+}\right]_{i}$ response were continuously monitored for 10 min (10-s intervals).

Additional file 3: Video S3. The time-lapse imaging of ionomycininduced $\left[\mathrm{Ca}^{2+}\right]_{i}$ response and contraction of PI3K-C2 $\beta$ siRNA-transfected HASM. PI3K-C2 $\beta$ specific siRNA-transfected, the fluorescent $\mathrm{Ca}^{2+}$ indicator fluo-8 loaded HASM cells were stimulated with ionomycin $(0.3 \mu \mathrm{M})$ at $1 \mathrm{~min}$, and contractile responses and changes in $\left[\mathrm{Ca}^{2+}\right]_{i}$ response were continuously monitored for 10 min (10-s intervals).

Additional file 4: Video S4. The time-lapse imaging of ionomycininduced $\left[\mathrm{Ca}^{2+}\right]_{i}$ response and contraction of PI3K-C2 $a$ and $-\mathrm{C} 2 \beta$ siRNAtransfected HASM. PI3K-C2 $a$ and -C2 $\beta$ specific siRNA-transfected, the fluorescent $\mathrm{Ca}^{2+}$ indicator fluo-8 loaded HASM cells were stimulated with ionomycin $(0.3 \mu \mathrm{M})$ at $1 \mathrm{~min}$, and contractile responses and changes in $\left[\mathrm{Ca}^{2+}\right]_{\mathrm{i}}$ response were continuously monitored for $10 \mathrm{~min}$ (10-s intervals).

Additional file 5: Video S5. The time-lapse imaging of RhoA-FRET in ionomycin-stimulated HASM. HASM cells were transfected with RhoAFRET probe expression vector and either control siRNA (left) or PI3K-C2a and $-\mathrm{C} 2 \beta$ specific siRNAs (right), and stimulated with ionomycin $(0.3 \mu \mathrm{M})$ at $1 \mathrm{~min}$. RhoA-FRET signals were monitored by confocal microscopy for $10 \mathrm{~min}$ (10 s-intervals). Note that the addition of ionomycin resulted in rapid activation of RhoA in control cells whereas ionomycin-induced RhoA activation was substantially reduced in C2a- and C2 $\beta$-depleted cells.

Additional file 6: Video S6. The time-lapse imaging of RhoA-FRET in ET1 -stimulated HASM. HASM cells were transfected with RhoA-FRET probe expression vector and either control siRNA (left) or PI3K-C2 $\alpha$ - and -C2 $\beta$ specific siRNAs (right), and stimulated with endothelin-1 $(1 \mu \mathrm{M})$ at $1 \mathrm{~min}$. RhoA-FRET signals were monitored by confocal microscopy for $10 \mathrm{~min}$ (10 s-intervals). Note that endothelin-1 resulted in rapid activation of RhoA in control cells whereas endothelin-1-induced RhoA activation was substantially reduced in C2a- and C2 $\beta$-depleted cells.

\section{Abbreviations}

PI3K: Phosphoinositide 3-kinases; C2a: Phosphoinositide 3-kinase-C2a; C2 $\beta$ : Phosphoinositide 3-kinase-C2 $\beta_{;}\left[\mathrm{Ca}^{2+}\right]_{;}$Intracellular free $\mathrm{Ca}^{2+}$ concentration; Cre: Cre recombinase; R26-tdTomato: Rosa26-CAG-loxP-stop-loxP-tdTomato; DAPI: 4',6-Diamidino-2-phenylindole; KO: Knockout; DKO: Double knockout; FRET: Fluorescence resonance energy transfer; GEF: Guanine nucleotide exchange factor; HBSS: Hanks'balanced salt solution; $\mathrm{MLC}_{20}$ : 20-kDa myosin light chain; MLCK: Myosin light chain kinase; MLCP: Myosin light chain phosphatase; IMC: Ionomycin; ET-1: Endothelin-1; NA: Noradrenaline; PI $(3,4) \mathrm{P}_{2}$ : Phosphatidylinositol 3,4-bisphosphate; SRRF: Super-resolution radial fluctuation; VEGF: Vascular endothelial growth factor; GFP: Green fluorescent protein; MASM: Mouse aortic smooth muscle cells; HASM: Human aortic smooth muscle cells; aSMA: a-Smooth muscle actin; BP: Blood pressure.

\section{Acknowledgements}

We thank Ms. Chiemi Hirose for secretarial assistance, and also thank the members of Department of Physiology for their support and assistance.

\section{Authors' contributions}

SI, KY, SA and YT designed the study. SI, KY, SA and HY performed experiments. KI helped experiments. SI, KY, SA and YT analyzed the data. SI, KY, NT and YT wrote the manuscript. All authors read and approved the final manuscript.

\section{Funding}

This study was supported by Grants from the Ministry of Education, Culture, Sports, Science and Technology (MEXT) of Japan (25116711 to Y.T.), and the Japan Society for the Promotion of Science (17K08532 to K.Y., 16K18988 to S.A., $16 \mathrm{~K} 15409$ to K.I., $17 \mathrm{~K} 08542$ to N.T., $15 \mathrm{H} 04673$ to Y.T.). The funders had no role in study design, data collection and analysis, decision to publish, or preparation of the manuscript.

\section{Availability of data and materials}

The data that support the findings of this study are available from the corresponding author on reasonable request.

\section{Ethics approval and consent to participate}

All mouse experiments were approved by the Committee on Animal Experimentation of Kanazawa University.

\section{Consent for publication}

Not applicable.

\section{Competing interests}

The authors declare that they have no conflict of interest.

\section{Author details}

${ }^{1}$ Department of Physiology, Kanazawa University Graduate School of Medical Sciences, 13-1 Takara-machi, Kanazawa, Ishikawa 920-8640, Japan. ${ }^{2}$ Department of Health Science, Ishikawa Prefectural University, Kahoku, Ishikawa 929-1210, Japan.

Received: 22 January 2020 Accepted: 10 March 2020

Published online: 19 March 2020

\section{References}

1. Janku F, Yap TA, Meric-Bernstam F (2018) Targeting the PI3K pathway in cancer: are we making headway? Nat Rev Clin Oncol 15:273-291. https:// doi.org/10.1038/nrclinonc.2018.28

2. Bilanges B, Posor Y, Vanhaesebroeck B (2019) PI3K isoforms in cell signalling and vesicle trafficking. Nat Rev Mol Cell Biol 20:515-534. https://doi. org/10.1038/s41580-019-0129-Z

3. Yoshioka K, Yoshida K, Cui H, Wakayama T, Takuwa N, Okamoto Y, Du W, Qi X, Asanuma K, Sugihara K, Aki S, Miyazawa H, Biswas K, Nagakura C, Ueno M, Iseki S, Schwartz RJ, Okamoto H, Sasaki T, Matsui O, Asano M, Adams RH, Takakura N, Takuwa Y (2012) Endothelial PI3K-C2a, a class II PI3K, has an essential role in angiogenesis and vascular barrier function. Nat Med 18:1560-1569. https://doi.org/10.1038/nm.2928

4. Gulluni F, De Santis MC, Margaria JP, Martini M, Hirsch E (2019) Class II PI3K functions in cell biology and disease. Trends Cell Biol 29:339-359. https:// doi.org/10.1016/j.tcb.2019.01.001

5. Aung KT, Yoshioka K, Aki S, Ishimaru K, Takuwa N, Takuwa Y (2019) The class II phosphoinositide 3-kinases PI3K-C2 $a$ and PI3K-C2 $\beta$ differentially regulate clathrin-dependent pinocytosis in human vascular endothelial cells. J Physiol Sci 69:263-280. https://doi.org/10.1007/s12576-018-0644-2

6. Marat AL, Haucke V (2016) Phosphatidylinositol 3-phosphates-at the interface between cell signalling and membrane traffic. EMBO J 35:561-579. https://doi.org/10.15252/embj.201593564

7. Wallroth A, Koch PA, Marat AL, Krause E, Haucke V (2019) Protein kinase $\mathrm{N}$ controls a lysosomal lipid switch to facilitate nutrient signalling via mTORC1. Nat Cell Biol 21:1093-1101. https://doi.org/10.1038/s4155 6-019-0377-3

8. Franco I, Gulluni F, Campa CC, Costa C, Margaria JP, Ciraolo E, Martini M, Monteyne D, De Luca E, Germena G, Posor Y, Maffucci T, Marengo S, Haucke V, Falasca M, Perez-Morga D, Boletta A, Merlo GR, Hirsch E (2014) PI3K class II alpha controls spatially restricted endosomal Ptdlns3P and Rab11 activation to promote primary cilium function. Dev Cell 28:647-658. https://doi.org/10.1016/j.devcel.2014.01.022

9. Falasca M, Maffucci T (2012) Regulation and cellular functions of class II phosphoinositide 3-kinases. Biochem J 443:587-601. https://doi. org/10.1042/BJ20120008

10. Domin J, Pages F, Volinia S, Rittenhouse SE, Zvelebil MJ, Stein RC, Waterfield MD (1997) Cloning of a human phosphoinositide 3-kinase with a 
C2 domain that displays reduced sensitivity to the inhibitor wortmannin. Biochem J 326:139-147. https://doi.org/10.1042/bj3260139

11. Stein RC, Waterfield MD (2000) PI3-kinase inhibition: a target for drug development? Mol Med Today 6:347-357. https://doi.org/10.1016/s1357 $-4310(00) 01770-6$

12. Wang Y, Yoshioka K, Azam MA, Takuwa N, Sakurada S, Kayaba Y, Sugimoto N, Inoki I, Kimura T, Kuwaki T, Takuwa Y (2006) Class II phosphoinositide 3-kinase a-isoform regulates Rho, myosin phosphatase and contraction in vascular smooth muscle. Biochem J 394:581-592. https://doi. org/10.1042/BJ20051471

13. Yoshioka K, Sugimoto N, Takuwa N, Takuwa Y (2007) Essential role for class Il phosphoinositide 3-kinase a-isoform in $\mathrm{Ca}^{2+}$-induced, Rho- and Rho kinase-dependent regulation of myosin phosphatase and contraction in isolated vascular smooth muscle cells. Mol Pharmacol 71:912-920. https ://doi.org/10.1124/mol.106.032599

14. Azam MA, Yoshioka K, Ohkura S, Takuwa N, Sugimoto N, Sato K, Takuwa $Y(2007) \mathrm{Ca}^{2+}$-independent, inhibitory effects of cyclic adenosine 5'-monophosphate on $\mathrm{Ca}^{2+}$ regulation of phosphoinositide 3-kinase C2a, Rho, and myosin phosphatase in vascular smooth muscle. J Pharmacol Exp Ther 320:907-916. https://doi.org/10.1124/jpet.106.111443

15. Seok YM, Azam MA, Okamoto Y, Sato A, Yoshioka K, Maeda M, Kim I, Takuwa Y (2010) Enhanced $\mathrm{Ca}^{2+}$-dependent activation of phosphoinositide 3-kinase class II a isoform-Rho axis in blood vessels of spontaneously hypertensive rats. Hypertension 56:934-941. https://doi. org/10.1161/HYPERTENSIONAHA.110.160853

16. Harada K, Truong AB, Cai T, Khavari PA (2005) The class II phosphoinositide 3-kinase C2beta is not essential for epidermal differentiation. Mol Cell Biol 25:11122-11130. https://doi.org/10.1128/MCB.25.24.11122-11130.2005

17. Sarker MAK, Aki S, Yoshioka K, Kuno K, Okamoto Y, Ishimaru K, Takuwa N, Takuwa Y (2019) Class II PI3Ks a and $\beta$ are required for Rho-dependent uterine smooth muscle contraction and parturition in mice. Endocrinology 160:235-248. https://doi.org/10.1210/en.2018-00756

18. Cui H, Okamoto Y, Yoshioka K, Du W, Takuwa N, Zhang W, Asano M, Shibamoto T, Takuwa Y (2013) Sphingosine-1-phosphate receptor 2 protects against anaphylactic shock through suppression of endothelial nitric oxide synthase in mice. J Allergy Clin Immunol 132:1205-1214. https:// doi.org/10.1016/j.jaci.2013.07.026

19. Kitatani K, Usui T, Sriraman SK, Toyoshima M, Ishibashi M, Shigeta S, Nagase S, Sakamoto M, Ogiso H, Okazaki T, Hannun Y (2016) Ceramide limits phosphatidylinositol-3-kinase C $2 \beta$-controlled cell motility in ovarian cancer: potential of ceramide as a metastasis-suppressor lipid. Oncogene 35:2801-2812. https://doi.org/10.1038/onc.2015.330

20. Wirth A, Wang S, Takefuji M, Tang C, Althoff TF, Schweda F, WettschureckOffermanns WNN (2016) Age-dependent blood pressure elevation is due to increased vascular smooth muscle tone mediated by G-protein signaling. Cardiovasc Res 109:131-140. https://doi.org/10.1093/cvr/cvv24 9

21. Mendelsohn ME (2005) In hypertension, the kidney is not always the heart of the matter. J Clin Invest 115:840-844. https://doi.org/10.1172/ JCl24806

22. Guyenet PG (2006) The sympathetic control of blood pressure. Nat Rev Neurosci 7:335-346. https://doi.org/10.1038/nrn1902

23. Sakurada S, Okamoto H, Takuwa N, Sugimoto N, Takuwa Y (2001) Rho activation in excitatory agonist-stimulated vascular smooth muscle. Am J Physiol Cell Physiol 281:571-578. https://doi.org/10.1152/ajpce II.2001.281.2.C571

24. Ito M, Nakano T, Erdodi F, Hartshorne DJ (2004) Myosin phosphatase: structure, regulation and function. Mol Cell Biochem 259:197-209. https ://doi.org/10.1023/b:mcbi.0000021373.14288.00

25. Stull JT, Lin PJ, Krueger JK, Trewhella J, Zhi G (1998) Myosin light chain kinase: functional domains and structural motifs. Acta Physiol Scand 164:471-482. https://doi.org/10.1111/j.1365-201x.1998.tb10699.x
26. Somlyo AP, Somlyo AV (2003) $\mathrm{Ca}^{2+}$ sensitivity of smooth muscle and nonmuscle myosin II: modulated by G proteins, kinases, and myosin phosphatase. Physiol Rev 83:1325-1358. https://doi.org/10.1152/physr ev.00023.2003

27. Sakurada S, Takuwa N, Sugimoto N, Wang Y, Seto M, Sasaki Y, Takuwa $Y(2003) \mathrm{Ca}^{2+}$-dependent activation of Rho and Rho kinase in membrane depolarization-induced and receptor stimulation-induced vascular smooth muscle contraction. Circ Res 93:548-556. https://doi. org/10.1161/01.RES.0000090998.08629.60

28. Janssen L, Tazzeo T, Zuo J, Pertens E, Keshavjee S (2004) KCl evokes contraction of airway smooth muscle via activation of RhoA and Rhokinase. Am J Physiol Lung Cell Mol Physiol 287:L852-L858. https://doi. org/10.1152/ajplung.00130.2004

29. Pertz O, Hodgson L, Klemke RL, Hahn KM (2006) Spatiotemporal dynamics of RhoA activity in migrating cells. Nature 440:1069-1072. https://doi. org/10.1038/nature04665

30. Machacek M, Hodgson L, Welch C, Elliott H, Pertz O, Nalbant P, Abell A, Johnson GL, Hahn KM, Danuser G (2009) Coordination of Rho GTPase activities during cell protrusion. Nature 461:99-103. https://doi. org/10.1038/nature08242

31. Ngok SP, Geyer R, Liu M, Kourtidis A, Agrawal S, Wu C, Seerapu HR, LewisTuffin L, Moodie KL, Huveldt D, Marx R, Baraban JM, Storz P, Horowitz A, Anastasiadis PZ (2012) VEGF and angiopoietin-1 exert opposing effects on cell junctions by regulating the Rho GEF Syx. J Cell Biol 199:11031115. https://doi.org/10.1083/jcb.201207009

32. Wu C, Horowitz A (2011) Membrane traffic as a coordinator of cell migration and junction remodeling. Commun Integr Biol 4:703-705. https:// doi.org/10.4161/cib.17140

33. Gaidarov I, Smith ME, Domin J, Keen JH (2001) The class II phosphoinositide 3-kinase C2a is activated by clathrin and regulates clathrin-mediated membrane trafficking. Mol Cell 7:443-449. https://doi.org/10.1016/ s1097-2765(01)00191-5

34. Posor Y, Eichhorn-Gruenig M, Puchkov D, Schoneberg J, Ullrich A, Lampe A, Muller R, Zarbakhsh S, Gulluni F, Hirsch E, Krauss M, Schultz C, Schmoranzer J, Noe F, Haucke V (2013) Spatiotemporal control of endocytosis by phosphatidylinositol-3,4-bisphosphate. Nature 499:233-237. https://doi. org/10.1038/nature 12360

35. Wallroth A, Haucke V (2018) Phosphoinositide conversion in endocytosis and the endolysosomal system. J Biol Chem 293:1526-1535. https://doi. org/10.1074/jbc.R117.000629

36. Aki S, Yoshioka K, Okamoto Y, Takuwa N, Takuwa Y (2015) Phosphatidylinositol 3-kinase class II a-isoform PI3K-C2a is required for transforming growth factor $\beta$-induced smad signaling in endothelial cells. J Biol Chem 290:6086-6105. https://doi.org/10.1074/jbc.M114.601484

37. Aki S, Yoshioka K, Takuwa N, Takuwa Y (2020) TGF $\beta$ receptor endocytosis and Smad signaling require synaptojanin1-, PI3K-C2a-, and INPP4Bmediated phosphoinositide conversions. Mol Biol Cell. https://doi. org/10.1091/mbc.E19-11-0662

38. Takuwa Y (2003) Regulation of the Rho signaling pathway by excitatory agonists in vascular smooth muscle. Adv Exp Med Biol 538:67-75

39. Takuwa Y, Yoshioka K, Takuwa N, Wang Y, Azam MA, Sugimoto N (2005) Calcium-dependent regulation of Rho and myosin phosphatase in vascular smooth muscle. Biomed Rev 16:13-21

\section{Publisher's Note}

Springer Nature remains neutral with regard to jurisdictional claims in published maps and institutional affiliations. 